Review

\title{
Extraction, Characterization, and Applications of Pectins from Plant By-Products
}

\author{
Anissa Belkheiri ${ }^{1}$, Ali Forouhar ${ }^{2}$, Alina Violeta Ursu ${ }^{1}$, Pascal Dubessay ${ }^{1}$, Guillaume Pierre ${ }^{1}$, \\ Cedric Delattre ${ }^{1,3}{ }^{\mathbb{D}}$, Gholamreza Djelveh ${ }^{1}$, Slim Abdelkafi ${ }^{4} \mathbb{D}$, Nasser Hamdami ${ }^{2} \mathbb{D}$ and Philippe Michaud ${ }^{1, * \mathbb{C}}$ \\ 1 CNRS, SIGMA Clermont, Institut Pascal, Université Clermont Auvergne, F-63000 Clermont-Ferrand, France; \\ anissa.belkheiri@etu.uca.fr (A.B.); alina_violeta.ursu@uca.fr (A.V.U.); pascal.dubessay@uca.fr (P.D.); \\ guillaume.pierre@uca.fr (G.P.); cedric.delattre@uca.fr (C.D.); gholamreza.djelveh@sigma-clermont.fr (G.D.) \\ 2 Food Science and Technology Department, College of Agriculture, Isfahan University of Technology, \\ Isfahan 84156, Iran; a.forouhar@ag.iut.ac.ir (A.F.); hamdami@cc.iut.ac.ir (N.H.) \\ 3 Institut Universitaire de France, 1 Rue Descartes, 75005 Paris, France \\ 4 Laboratoire de Génie Enzymatique et Microbiologie, Equipe de Biotechnologie des Algues, Ecole Nationale \\ d'Ingénieurs de Sfax, Université de Sfax, Sfax 3029, Tunisia; slim.abdelkafi@enis.tn \\ * Correspondence: philippe.michaud@uca.fr; Tel.: +33-473407425
}

Citation: Belkheiri, A.; Forouhar, A.; Ursu, A.V.; Dubessay, P.; Pierre, G.; Delattre, C.; Djelveh, G.; Abdelkafi, S. Hamdami, N.; Michaud, P. Extraction Characterization, and Applications of Pectins from Plant By-Products. Appl. Sci. 2021, 11, 6596. https://doi.org/ 10.3390/app11146596

Academic Editor: Gohar Khachatryan

Received: 14 June 2021

Accepted: 14 July 2021

Published: 18 July 2021

Publisher's Note: MDPI stays neutral with regard to jurisdictional claims in published maps and institutional affiliations.

Copyright: (c) 2021 by the authors. Licensee MDPI, Basel, Switzerland. This article is an open access article distributed under the terms and conditions of the Creative Commons Attribution (CC BY) license (https:/ / creativecommons.org/licenses/by/ $4.0 /)$.

\begin{abstract}
Currently, pectins are widely used in the cosmetic, pharmaceutical, and food industries, mainly as texturizing, emulsifying, stabilizing, and gelling agents. Pectins are polysaccharides composed of a large linear segment of $\alpha-(1,4)$ linked D-galactopyranosyluronic acids interrupted by $\beta$ $(1,2)$-linked L-rhamnoses and ramified by short chains composed of neutral hexoses and pentoses. The characteristics and applications of pectins are strongly influenced by their structures depending on plant species and tissues but also extraction methods. The aim of this review is therefore to highlight the structures of pectins and the various methods used to extract them, including conventional ones but also microwave heating, ultrasonic treatment, and dielectric barrier discharge techniques, assessing physico-chemical parameters which have significant effects on pectin characteristics and applications as techno-functional and bioactive agents.
\end{abstract}

Keywords: pectin; extraction method; techno-functional properties; agricultural waste

\section{Introduction}

Among the $30 \%$ of foods wasted annually, $45 \%$ are from fruits and vegetables. The drink industry (26\%), followed by the dairy and ice cream industry $(21.3 \%)$ and the production and preservation of fruits and vegetables (14.8\%), produces the largest amounts of food wastes [1]. Effective utilization of food wastes protects the environment and shows great potential for the production of functional substances such as bioactive secondary metabolites, essential oils, pigments, enzymes, and non-starch polysaccharides [2]. The recovery of non-starch polysaccharides from fruit by-products is a promising strategy for the development of natural biopolymers, although pectin is currently extracted from citrus and apple wastes [3].

Watermelon (Citrullus lanatus) is an important crop around the world and is native to Africa. It has been cultivated for thousands of years in many Middle Eastern and South-East Asian countries. Currently, China, Turkey, and Iran are the leading watermelon-producing countries (https:/ / www.worldatlas.com/articles/top-watermelon-producing-countriesin-the-world.html (accessed on 15 July 2021)). Spain is the main producer of watermelon for the European community. Watermelon has been introduced as a source of vitamins (A, $\mathrm{B}, \mathrm{C}$, and $\mathrm{E})$, free amino acids (citrulline and arginine), mineral salts $(\mathrm{Mg}, \mathrm{K}, \mathrm{Ca}$, and $\mathrm{Fe})$, carotenoids, and phenolic compounds (such as flavonoids and lycopene) [4]. The citrulline in watermelon rinds gives it antioxidant effects. Citrulline is good for the heart, circulatory system, and immune system [5]. Watermelon biomass can be categorized into three main 
components, which are the flesh, seed, and rind. The watermelon rind, the area of whitecolored flesh between the colored flesh and the outer skin, accounts for approximately one-third of the total fruit mass [6]. The rind contains mineral salts (13.09\%), fat (2.44\%), protein $(11.17 \%)$, carbohydrates (56\%), vitamins, and phytochemicals [7]. Carbohydrates are the main compounds of the watermelon rind which can be a raw material for pectin extraction. However, it is considered as waste and has no commercial value [8].

Pectins are a family of complex polysaccharides present within the primary cell wall and intercellular regions of dicotyledons, that impart flexibility and mechanical strength to plants [9]. In the 1920s and 1930s, many companies began producing pectin because of the large quantities of fruit left over from the juice and wine industries, especially apple or citrus pulps [10]. Pectins are used in the cosmetics, pharmaceutical, and food industries to stabilize acidified milk drinks or juice and as a gelling or thickening agent. In Europe, they are an approved food additive, coded E440a for low- and high-methoxyl pectins and E440b for amidated pectin [11]. Pectins have also been the subject of special attention from nutritionists. They are used as dietary fiber and exert physiological effects on the intestinal tract by increasing the transit time and the absorption of glucose [12].

\section{Structure and Production of Pectins}

\subsection{Structure}

Pectin compositions and structures are strongly dependent on the pectin source, developmental stages of plants, and extraction conditions. Pectin is composed of Dgalacturonic acids (GalpA) $\alpha$ - $(1,4)$ linked to form a backbone interrupted by $(1,2)$-linked $\beta$ L-rhamnose (Rhap) [13]. Indeed, they encompass a very complex group of polysaccharides covalently linked to each other and the most abundant classes are homogalacturonan (HG) and rhamnogalacturonan I (RG-I). Minor components are substituted galacturonans which include rhamnogalacturonan II (RG-II), xylogalacturonan (XGA), and apiogalacturonan (AGA). The latter has been reported only in aquatic plants (Figure 1). In dicots, ferulates are ester linked to arabinose and galactose residues in pectin. On the backbone, a proportion of the carboxyl groups can be methyl esterified, while a certain number of short chains composed of galactose (Galp), arabinose (Ara), xylose, and glucuronic acid (GlcpA) might be present as side chains (hairy regions). Acetyl groups can esterify Galp A at C2 and/or C3 positions, giving a degree of acetylation (DAC) (especially in sunflower or beet pectins) (Figure 2). Mono- or divalent ions can neutralize carboxylic groups of pectins. The pectic chains, in a solid state or solution, have a helical conformation $[6,14]$.

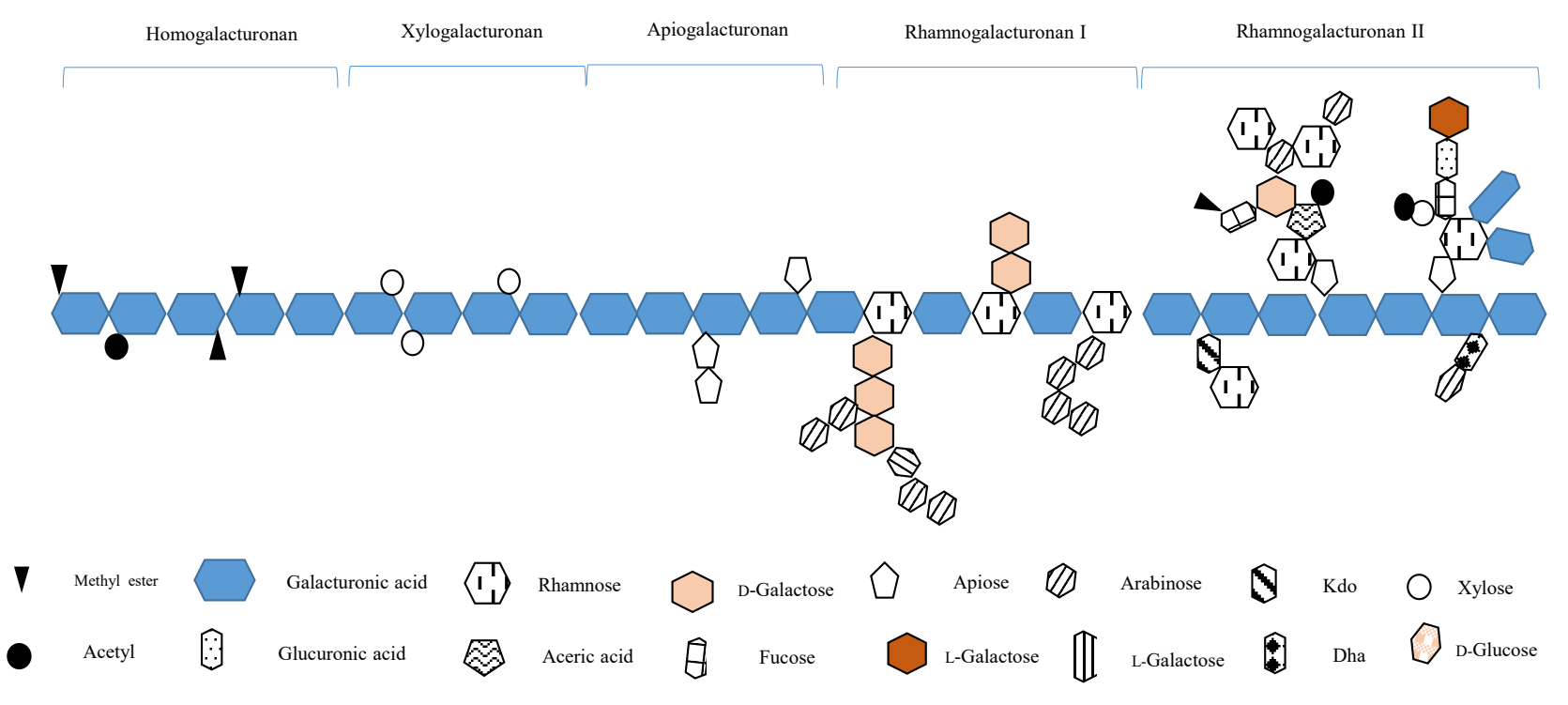

Figure 1. Pectin structure $[15,16]$. 


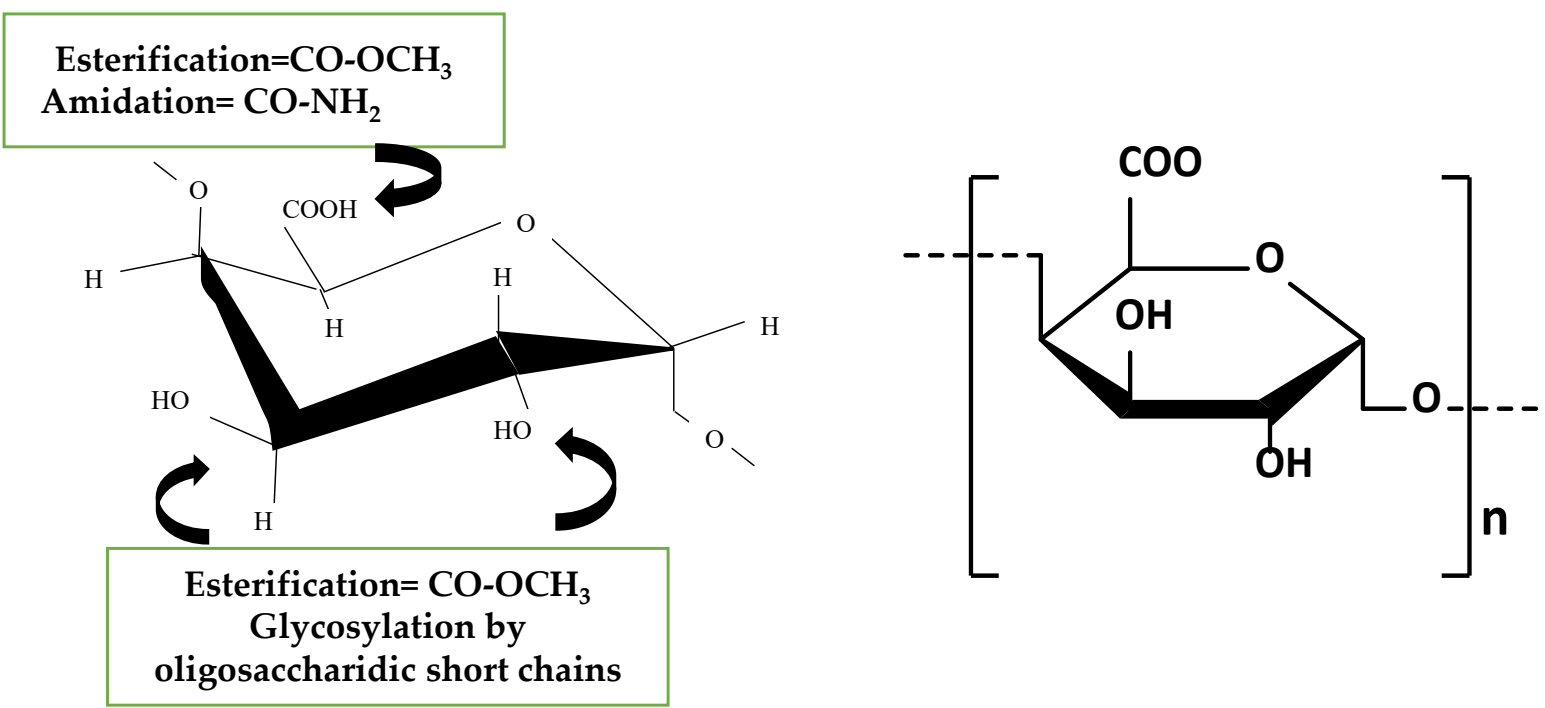

Figure 2. Substitution of galacturonic acid [17].

\subsubsection{Homogalacturonan}

Partially C-6 carboxylated and O-2 or O-3 acetylated HGs are the most abundant forms in pectin $[2,18]$ as they represent between $57 \%$ to $70 \%$ of them [19]. The methyl esterification of the homogalacturonan regions partly determines the extent of industrial applications of pectins and their capacity for interaction [20]. This methyl esterification corresponds to the degree of methylation (DM) as a percentage. HGs form the smooth zone of pectins.

\subsubsection{Rhamnogalacturonan I}

RG-I (Figure 1) is a region that makes up $7-14 \%$ of the pectin and is made up of alternating Galp $\mathrm{A}$ and Rha. Interruption of the galacturonan backbone by L-Rha, forming a $(1,4)-\alpha$-D-galacturonic acid-(1,2)- $\alpha$-L-rhamnose repeating unit, forms the backbone of rhamnogalacturonan I [21]. Twenty to eighty percent of L-Rha present in this region is substituted by Gal $p$ or Ara at the C-4 position. The GalpA residues from this region can also be methylated or acetylated but at a lower frequency compared with homogalacturonan regions $[14,19]$. In some plants (beetroot, spinach, etc.), the side chains can be substituted by phenolic acids (ferulic or coumaric acids) esterifying the alcohol functions in position 6 of galactose residues or in position 2 of arabinoses [22].

\subsubsection{Rhamnogalacturonan II}

RG-II (Figure 1) is a substituted galacturonan representing 10 to $11 \%$ of the pectin and whose complex structure is highly conserved in plant species [19]. RG-II exists in primary walls as a dimer covalently cross-linked by a borate diester. It comprises at least eight galacturonic acids linked in 1-4 and constituting the main chain, onto which four different glycosidic complexes are grafted. These glycosidic complexes are composed of arabinofuranose, arabinopyranose, glucopyranose, fucopyranose, apiofuranose, galactopyranose, and other unusual sugars such as 3-deoxy-D-lyxo-2-heptulosaric acid (Dha), ketodeoxyoctonic acid (Kdo), and aceric acid. They also contain rare methylated sugars such as 2-O-methylxylose and 2-O-methylfucose [23].

\subsubsection{Xylogalacturonan and Apiogalacturonan}

Xygolacturoanan and apiogalacturonan are regions found to be much less complex (Figure 1). They have a homogalacturonan structure substituted with xylose for xylogalacturonan and monosaccharide or disaccharide apiofuranosyl for apiogalacturonan [23]. 
The pectin extracted from unconventional resources such as watermelon rind is mainly composed of linear HG chains $(71.8 \%)$ with a high degree of esterification and the RG-I $(25.8 \%)$ region is substituted with short chains of $\beta-(1-4)$ galactans. Its monosaccharide composition consists of galacturonic acid $(74 \%)$, galactose $(20.2 \%)$, rhamnose $(2.4 \%)$, glucose $(1.4 \%)$, arabinose $(0.7 \%)$, xylose $(0.5 \%)$, mannose $(0.4 \%)$, and fucose $(0.2 \%)$ [6].

\subsection{Structure Classification}

\subsubsection{Degree of Methylation}

Pectins can be classified according to their degree of methylation (DM) [1] expressed as a percentage, which corresponds to the number of methylated carboxylic functions per 100 units of galacturonic acid in the main chain. According to their degree of methylation, a distinction is made between:

- High-methoxyl (HM) pectin (Figure 3A) with a DM > 50\%, mostly present in nature as native pectin.

- Low-methoxyl (LM) pectin (Figure 3B) with a DM $<50 \%$. This LM pectin is only obtained after demethylation by enzymatic (methylesterases) or alkaline treatments of HM pectin. There are also several unconventional sources of low-methoxy pectin.
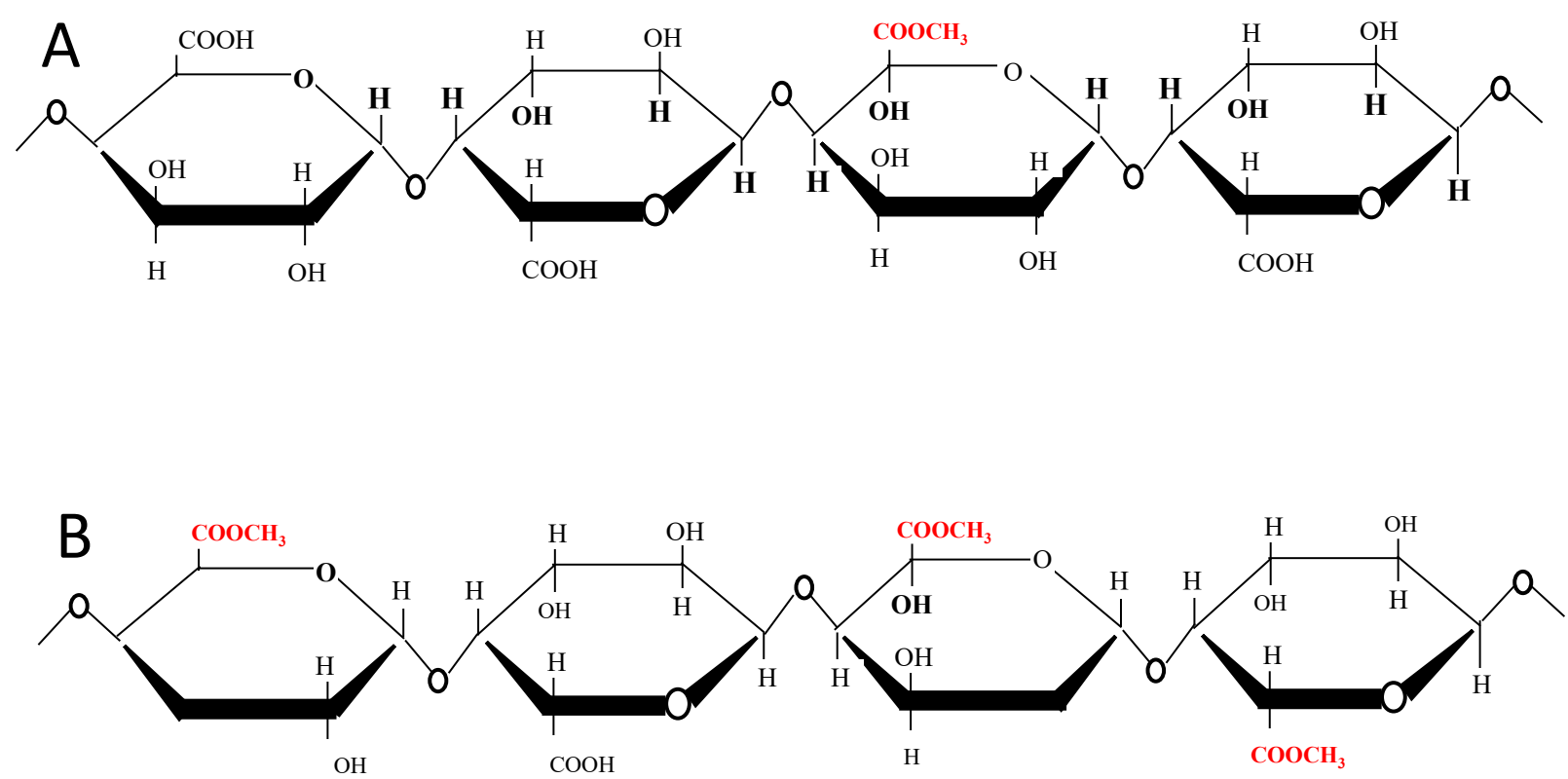

Figure 3. Partially methylated galacturonans. (A) Low-methoxyl and (B) high-methoxyl pectin structures [11].

The methoxyl content reflects the dispersibility of pectin in water and its ability to form a hydrogel [24]. Low- and high-methoxyl pectins have different physico-chemical properties and thus diverse applications. The degree of methylation of the extracted pectin depends on the type of plant, its age, and degree of maturation (notably for fruits). Therefore, pectins from fruits do not have the same degree of methylation. Pectins with a low degree of methylation form gels in the presence of calcium ions whereas those with a high degree of methylation gellify with the addition of different sugars, such as sucrose, under acidic conditions $[10,25]$. The extraction methods affect the structure of pectin.

\subsubsection{Degrees of Acetylation and Amidation}

The degree of acetylation (DAC) is defined as the percentage of galacturonosyl residues esterified (on the hydroxyl group) with acetyl (Figure 1). Acetylation prevents gel formation but increases the stabilizing and emulsifying effects of pectins [26-28]. The presence of multiple acetyl groups on sugar beet pectin gives it a surfactant behavior that can be used to stabilize emulsions [29,30]. Pectins having a high degree of acetylation (DAC up to 25\%) do not have good gelling properties [11]. 
Amidated pectins are synthetized through the reaction of pectin carboxymethyl groups $\left(-\mathrm{COOCH}_{3}\right)$ with ammonia [31,32]. The degree of amidation (DA) is the percentage of carboxylic groups in the amide form. It mainly concerns weakly low-methoxy amidated pectin (LMAP). The amidation of pectin enables it to withstand more calcium variation and be more thermoreversible [31]. It also increases the water solubility of pectins [32].

\section{Pectin Extraction Methods}

Extraction of pectin is governed by mass transfer into the process medium and thus the suitability of the extraction method can be assessed by the yield and quality of extracted pectins [2]. The pectin in the cell wall is insoluble and is called "protopectin". Its extraction begins by hydrolysis of the protopectin with a hot diluted mineral acid. The bonds between the sugars on the side chains and the cell wall are broken and the pectin is released into the aqueous medium [33]. The pectin is then concentrated and separated in various ways and finally dried (Figure 4).

\subsection{Traditional Methods for the Pectin Extraction}

In industry, pectin extraction is generally performed using strong acid solutions such as nitric, sulfuric, phosphoric, and hydrochloric acids, under heating [34]. Conventional pectin extraction takes several hours to obtain a good yield using boiling water [35,36]. During the long heating process, the thermal degradation of pectins by beta-elimination and debranching leads to low-quality pectins. Therefore, pectin is extracted in acidic aqueous medium ( $\mathrm{pH} 1.5-3$ ) between 75 and $100{ }^{\circ} \mathrm{C}$ for $1-3 \mathrm{~h}$ with continuous stirring. In pectin extraction, the use of mineral acids has been related to environmental issues and increased costs. With regard to the emerging concept of "green chemistry" and "green technology", the focus is now shifting to organic acids (acetic and citric acids). Organic acids possess lower hydrolysis abilities compared to mineral ones [2]. Conventional extraction depends on several factors, such as temperature, $\mathrm{pH}$, solvent properties, solid to solvent ratio, particle size, and diffusion rate [1]. After pretreatments of washing with water, blanching with hot water to inactivate enzymes, drying to remove water, and grinding to increase the exchange surface, pectin is extracted in an acidic aqueous medium and separated by alcohol precipitation from many other materials. The coagulate obtained is then filtered to clarify the extract, washed, dried under vacuum, and finally ground into a fine powder. Between the filtration and washing, the extract can undergo different steps. For example, the color of apple pectin can be removed by using activated carbon, and the residual starch can be degraded using amylase. Additionally, chemical, acid, and/or alkaline de-esterification can be used to obtain LM pectin. The extracted pectins generally have a DM between 55 and $75 \%$ and high molecular weights. The choice of solvent is based on several criteria, which are: dissolving of the specific components, high capacity for the solute separated into it, selectivity, stability, renewability, and low viscosity [37]. Chelating agents (CHAs), such as oxalate, have been used for pectin extraction. The efficiency of chelating agents for pectin extractions is impacted by the $\mathrm{Ca}^{2+}$ content and the distribution of free acid groups in the HG chain [36]. CHAs solubilize high molecular weight pectins with a high DM [38]. Acidic aqueous medium with low $\mathrm{pH}$ stimulates protopectin hydrolysis and solubility and promotes $\mathrm{Ca}^{2+}$ and $\mathrm{Mg}^{2+}$ removal, thus enabling higher isolated yields of HGenriched pectin. Alkaline-extracted pectins have usually many RG-I oligomers branched with arabinan and galactan side chains, low DM, and low yields [36]. Conventional pectin extraction using mineral acids has some important drawbacks, such as degradation of pectin, losses of some volatile compounds, increased costs for manufacturers, and environmental problems. Therefore, organic acids such as citric and acetic acids have attracted considerable interest [39]. Although strong mineral acids are cheaper and more effective than organic acids to extract pectin, The use of organic acid in the extraction of pectin leads to less hydrolysis and less depolymerization of the extracted pectin than the use of mineral acid [1]. Using citric acid with microwave heating provided higher DE values than using $\mathrm{HCl}$ with the same method [40]. This might have been due to the strong 
acid causing the demethylation and fragmentation of polygalacturonans [41]. Citric acid was reported to be a less pectin-degrading agent compared to $\mathrm{HCl}$ [2]. It is expected that the pectin extracted with organic acid as a solvent has a higher molecular weight compared to that of pectin extracted using mineral acid. The degree of esterification decreases with increasing heating time $[42,43]$. Different extraction methods lead to the production of pectins with different DEs [41,44,45]. A low-viscosity solvent must be used as it easily enter into the plant matrix [42]. Time and temperature have a destructive effect on the plant cell wall. As a result, they facilitate solvent diffusion and pectin extraction. In the extraction process, high temperature allows the solubilization of pectins and increases the yields [46]. However, pectin extraction at very high temperatures has been related to the hydrolysis of pectin into short chains which are not precipitated by ethanol, affecting the yields [47]. High temperatures also reduce the degree of esterification of pectin [27]. From the perspective of the extraction time, it should be enough for the solvent to dissolve a sufficient amount of the target component since the extraction occurs until equilibrium is reached. On the other hand, a long extraction time can cause pectin degradation [34]. Therefore, to achieve the desired conditions, the extraction temperature and time have to be optimized [48]. The solid/liquid ratio is usually maintained between 1:10 and 1:50 for pectin extraction. When this ratio is less than 1:10, it leads to low pectin yields because the amount of solvent is not enough to dissolve and extract the pectin. An increase is found in the solid-liquid ratio (up to $1: 30 \mathrm{~m} / \mathrm{v}$ ) increments regarding the pectin yield due to the rise in dissolution capacity. Pectin extraction yield increases following an increase in the solid to liquid ratio through an increase in the dissolution capacity $[27,34]$. The surface area of the material and agitation are also effective in the pectin extraction process. Table 1 summarizes the different extraction conditions in the conventional extraction method.

Table 1. Extraction conditions and physico-chemical properties of pectin extracted by CHE from agricultural waste, food by-products, and others.

\begin{tabular}{|c|c|c|c|c|c|c|c|c|c|c|c|}
\hline \multirow{2}{*}{$\begin{array}{l}\text { Pectin } \\
\text { Sources }\end{array}$} & \multicolumn{6}{|c|}{ Extraction Conditions } & \multirow{2}{*}{ Yield (\%) } & \multirow{2}{*}{ DM (\%) } & \multirow{2}{*}{ GalA (\%) } & \multirow{2}{*}{$\begin{array}{c}\text { Mw } \\
(\mathrm{kg} / \mathrm{mol})\end{array}$} & \multirow{2}{*}{ Reference } \\
\hline & Treatments & Solvents & Temperatures & $\mathrm{pH}$ & $\mathrm{S} / \mathrm{L}$ & Time & & & & & \\
\hline $\begin{array}{l}\text { Grapefruit } \\
\text { peel }\end{array}$ & $\mathrm{CHE}$ & $\mathrm{HCl}$ & $80^{\circ} \mathrm{C}$ & 1.5 & $1: 50$ & $90 \mathrm{~min}$ & 23.50 & 67.59 & 55.20 & 132.01 & [49] \\
\hline $\begin{array}{c}\text { Fresh } \\
\text { watermelon } \\
\text { rinds }\end{array}$ & $\mathrm{CHE}$ & $\begin{array}{l}\mathrm{HNO}_{3} \\
(0.1 \mathrm{M})\end{array}$ & BT & - & $1: 25$ & $1 \mathrm{~h}$ & 19.3 & 63.0 & 74.2 & 34.510 & {$[6]$} \\
\hline Passionfruit & $\mathrm{CHE}$ & $\mathrm{HCI}$ & $98.7^{\circ} \mathrm{C}$ & 2 & $1: 30$ & $60 \mathrm{~min}$ & 14.8 & 9.57 & 88.2 & 802 & [27] \\
\hline Beet pulp & $\mathrm{CHE}$ & $\mathrm{HCl}$ & $80^{\circ} \mathrm{C}$ & 1 & $1: 50$ & $3 \mathrm{~h}$ & 20.0 & 58.92 & 66.18 & 116 & {$[50]$} \\
\hline Citron peels & $\mathrm{CHE}$ & citric acid & $95^{\circ} \mathrm{C}$ & 1.5 & $1: 30$ & 95 & 28.31 & 51.33 & - & - & [51] \\
\hline $\begin{array}{l}\text { Unripe } \\
\text { banana }\end{array}$ & $\mathrm{CHE}$ & citricacid & $86^{\circ} \mathrm{C}$ & 2.0 & $1: 50$ & $6 \mathrm{~h}$ & 11.63 & - & 11.21 & - & [52] \\
\hline $\begin{array}{l}\text { Eggplant } \\
\text { peel waste }\end{array}$ & $\mathrm{CHE}$ & citric acid & $90^{\circ} \mathrm{C}$ & 2.5 & $1: 40$ & 90 & 26.1 & 60.2 & 69.7 & - & [53] \\
\hline Medlar fruit & $\mathrm{CHE}$ & $\mathrm{HCI}$ & $89^{\circ} \mathrm{C}$ & 4.2 & $1: 25$ & $4.83 \mathrm{~h}$ & & 62.9 & 71.4 & 198 & [54] \\
\hline $\begin{array}{l}\text { Pomelo } \\
\text { peels }\end{array}$ & $\mathrm{CHE}$ & $\mathrm{HNO}_{3}$ & $90^{\circ} \mathrm{C}$ & 2 & $1: 30$ & 90 & 23.19 & 57.87 & 86.26 & 353 & [55] \\
\hline $\begin{array}{l}\text { Lyophilized } \\
\text { watermelon } \\
\text { rinds }\end{array}$ & $\mathrm{CHE}$ & $\begin{array}{l}\mathrm{HNO}_{3} \\
(0.1 \mathrm{M})\end{array}$ & BT & - & $1: 25$ & $1 \mathrm{~h}$ & 14.2 & 61.5 & 68.7 & 40.390 & [6] \\
\hline Cubiu fruit & $\mathrm{CHE}$ & $\mathrm{HNO}_{3}$ & BT & 1.5 & $1: 25$ & $2 \mathrm{~h}$ & 14.2 & $62 \%$ & $75.0 \%$ & 628 & [56] \\
\hline $\begin{array}{c}\text { Sweet } \\
\text { prickly pear }\end{array}$ & $\mathrm{CHE}$ & EDTA & $70{ }^{\circ} \mathrm{C}$ & 4.0 & $1: 3$ & $2 \mathrm{~h}$ & - & 26.83 & 65.23 & 204.08 & [57] \\
\hline $\begin{array}{l}\text { Cocoa pod } \\
\text { husks }\end{array}$ & $\mathrm{CHE}$ & $\begin{array}{l}\text { ascorbic } \\
\text { acid }\end{array}$ & $95^{\circ} \mathrm{C}$ & 2.5 & $1: 10$ & 45 & 4.2 & 8.1 & 74.5 & - & [58] \\
\hline $\begin{array}{l}\text { Stems of E. } \\
\text { arvense }\end{array}$ & $\mathrm{CHE}$ & $\begin{array}{l}\text { ammonium } \\
\text { oxalate }\end{array}$ & $70^{\circ} \mathrm{C}$ & & $1: 40$ & $8 \mathrm{hr}$ & 5.9 & 16 & 85 & 360 & [59] \\
\hline
\end{tabular}


Table 1. Cont.

\begin{tabular}{|c|c|c|c|c|c|c|c|c|c|c|c|}
\hline \multirow{2}{*}{$\begin{array}{l}\text { Pectin } \\
\text { Sources }\end{array}$} & \multicolumn{6}{|c|}{ Extraction Conditions } & \multirow{2}{*}{ Yield (\%) } & \multirow{2}{*}{$\operatorname{DM}(\%)$} & \multirow{2}{*}{ GalA (\%) } & \multirow{2}{*}{$\begin{array}{c}\text { Mw } \\
(\mathrm{kg} / \mathrm{mol})\end{array}$} & \multirow{2}{*}{ Reference } \\
\hline & Treatments & Solvents & Temperatures & $\mathrm{pH}$ & $\mathrm{S} / \mathrm{L}$ & Time & & & & & \\
\hline Papaya peel & $\mathrm{CHE}$ & $\mathrm{HCl}$ & $80^{\circ} \mathrm{C}$ & 2.0 & $1: 50$ & $60 \mathrm{~min}$ & 16 & 53.4 & 70.5 & - & {$[60]$} \\
\hline Potato pulp & $\mathrm{CHE}$ & citric acid & $90^{\circ} \mathrm{C}$ & 2.04 & $1: 15$ & $60 \mathrm{~min}$ & 14.34 & 37.45 & 24.3 & 320 & [39] \\
\hline $\begin{array}{l}\text { Carrot } \\
\text { pomace }\end{array}$ & $\mathrm{CHE}$ & - & $90^{\circ} \mathrm{C}$ & 1.3 & - & $\begin{array}{l}79.8 \\
\min \end{array}$ & 15.2 & 45.2 & 75.5 & - & [61] \\
\hline Lime peel & $\mathrm{CHE}$ & $\mathrm{HCl}$ & $95^{\circ} \mathrm{C}$ & - & $1: 40$ & $1 \mathrm{~h}$ & 15.91 & 78.49 & 89.8 & 794.7 & [40] \\
\hline Ponkan peel & $\mathrm{CHE}$ & $\mathrm{HNO}_{3}$ & - & 1.6 & $1: 36$ & $100 \mathrm{~min}$ & 25.6 & 85.7 & 84.5 & 80.6 & {$[62]$} \\
\hline Chicory & $\mathrm{CHE}$ & - & $80^{\circ} \mathrm{C}$ & 1.5 & $1: 20$ & $1 \mathrm{~h}$ & 12.2 & 44.7 & 71.9 & 260 & [63] \\
\hline $\begin{array}{l}\text { Sugar beet } \\
\text { pulp }\end{array}$ & CHE & - & $80^{\circ} \mathrm{C}$ & 1.5 & $1: 20$ & $1 \mathrm{~h}$ & 7.1 & 46.4 & 66.2 & 651 & [63] \\
\hline $\begin{array}{c}\text { Green tea } \\
\text { leaf }\end{array}$ & CHE & $\begin{array}{l}\text { deionized } \\
\text { water }\end{array}$ & $80^{\circ} \mathrm{C}$ & - & - & $3 \mathrm{~h}$ & 5.3 & 26.5 & 32.4 & 276 & [64] \\
\hline $\begin{array}{l}\text { Green tea } \\
\text { leaf }\end{array}$ & $\mathrm{CHE}$ & $\mathrm{HCl}$ & $60^{\circ} \mathrm{C}$ & 2 & - & $3 \mathrm{~h}$ & 6.1 & 21.1 & 31.8 & 396 & [64] \\
\hline $\begin{array}{l}\text { Green tea } \\
\text { leaf }\end{array}$ & $\mathrm{CHE}$ & $\mathrm{NaoH}$ & $60^{\circ} \mathrm{C}$ & 8 & - & $3 \mathrm{~h}$ & 9.2 & 24.7 & 41.6 & 334 & [64] \\
\hline $\begin{array}{c}\text { Apple } \\
\text { pomace }\end{array}$ & $\mathrm{CHE}$ & $\mathrm{HNO}_{3}$ & $90^{\circ} \mathrm{C}$ & 1.5 & $1: 25$ & 70 & 25.3 & 41.7 & 84.5 & 142 & [65] \\
\hline $\begin{array}{l}\text { Pomegranate } \\
\text { peel }\end{array}$ & $\mathrm{CHE}$ & $\mathrm{HNO}_{3}$ & $86^{\circ} \mathrm{C}$ & 1.7 & $1: 20$ & $80 \mathrm{~min}$. & 8.5 & 75 & 62.0 & 549 & [66] \\
\hline $\begin{array}{c}\text { Apple } \\
\text { pomace }\end{array}$ & $\mathrm{CHE}$ & $\mathrm{HNO}_{3}$ & BT & - & $1: 40$ & $10 \mathrm{~min}$ & 15.04 & 72.29 & 57.28 & - & [67] \\
\hline $\begin{array}{l}\text { Grapefruit } \\
\text { peel }\end{array}$ & $\mathrm{CHE}$ & $\mathrm{HCl}$ & $80^{\circ} \mathrm{C}$ & 1.5 & $1: 50$ & $1.5 \mathrm{~h}$ & - & 69.03 & 68.36 & 385.5 & [68] \\
\hline $\begin{array}{l}\text { Jackfruit } \\
\text { rinds }\end{array}$ & $\mathrm{CHE}$ & $\begin{array}{l}\text { distilled } \\
\text { water }\end{array}$ & $90^{\circ} \mathrm{C}$ & - & $1: 25$ & $1 \mathrm{~h}$ & 14.59 & - & 72.62 & - & [69] \\
\hline $\begin{array}{l}\text { Watermelon } \\
\text { peel }\end{array}$ & $\mathrm{CHE}$ & $\mathrm{H}_{2} \mathrm{SO}_{4}$ & $90^{\circ} \mathrm{C}$ & 1.0 & $1: 20$ & $150 \mathrm{~min}$ & 17.6 & 41.2 & 78.3 & 119 & [70] \\
\hline
\end{tabular}

S/L: solid-liquid ratio. DM: degree of methyl esterification. GalA: galacturonic acid content. Mw: molecular weight. CHE: conventional heating extraction. BT: boiling temperature. 


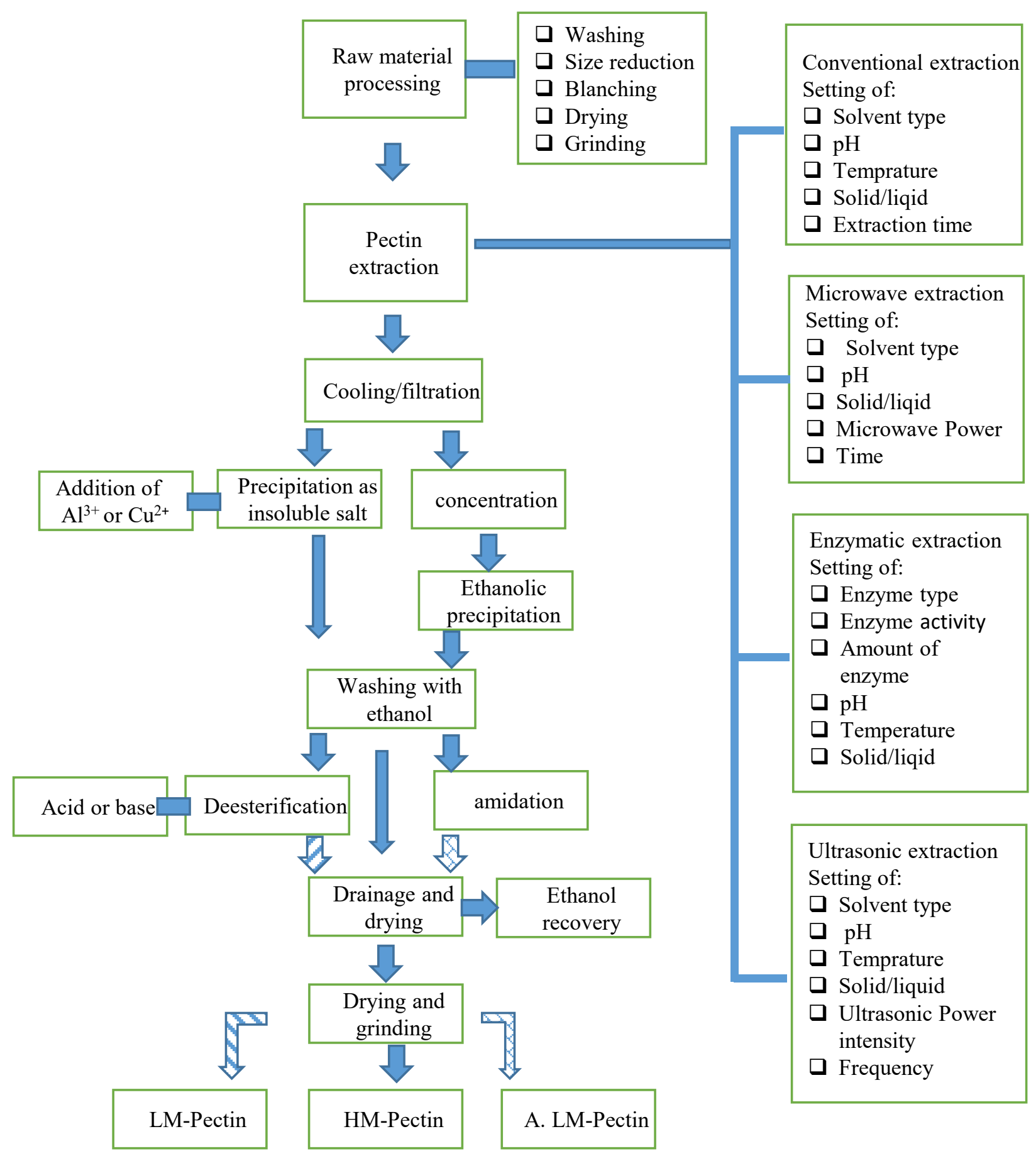

Figure 4. Pectin extraction process [71].

\subsection{Green methods for Pectin Extraction}

To improve the pectin quality and reduce the extraction time, it is necessary to investigate new extraction methods. This classic extraction method is widely used but has disadvantages, such as process time, low yield, and risk of pectin degradation. Thus, new green processes were implemented to increase the extraction efficiency (yield), preserve the techno-functional properties of the pectin, and decrease solvent consumption [1]. Some alternatives include microwave-assisted extraction, enzyme-assisted extraction, use of subcritical fluids, ultrasound (U)-assisted extraction, high hydrostatic pressure, and deep 
eutectic solvents or a combination of these methods (Figure 4) [72]. Some of these methods are discussed below.

\subsubsection{Microwave-Assisted Extraction}

Microwave-assisted extraction (MAE) is a green method in which a polar solvent absorbs microwave energy and consists of two oscillating perpendicular fields: electric and magnetic fields [73]. MAE is considered as a fast extraction method that involves electromagnetic radiation in the microwave frequency range in the sample to produce thermal energy in the solvent. Microwave energy initiates the electrophoretic transfer of ions and electrons which generates an electric field responsible for particle movements, while dipole rotation is caused by the alternate displacement of polar molecules [45]. Microwave energy increases the efficiency of the extraction process, compared with conventional heating techniques [41]. The heat generated is an important factor in the extraction process as the higher temperatures result in an increase in diffusion rate and, therefore, enhance extraction yields. In addition, the dielectric properties of the sample and solvent and solubility of the interesting compounds in the solvent also affect the extraction rate and quality of extracted compounds [2].

MAE could limit the pectin depolymerization that can be observed during acid extraction [74]. Microwave radiation has an impact on the cell wall matrix and leads to the severing of the parenchymal cells and, thereby, the skin tissues are extensively opened up. This could lead to increased interaction between the source material and solvent in the extraction process. Therefore, the permeation of the extracting solvent is increased [75] and extraction efficiency could be increased by increasing microwave power [1,2].

The increasing of the microwave irradiation energy can enhance the penetration of solvent into the plant matrix and deliver it efficiently to materials through molecular interaction with the electromagnetic field and offer a rapid transfer of energy to the solvent and matrix, allowing the dissolution of components to be extracted. Moreover, microwave irradiation can accelerate cell rupture through an internal pressure increase inside the cells of the plant sample and a sudden rise in temperature, which promotes the destruction of the sample surface and, in turn, the exudation of pectin from the plant cells into the solvent [76].

Hua et al. (2015) reported that the apparent viscosity of the pectin from microwave heating was greater than that from conventional heating. This could be explained by the difference in the methoxyl content and the heating method. A high methoxyl content means a small number of molecules and a greater distance between molecules, resulting in low viscosity of pectin extracted by conventional heating [77]. Table 2 summarizes the physico-chemical properties of pectins extracted by green methods, including MAE.

\subsubsection{Enzymatic Extraction}

Enzymes are used to improve the extraction process by hydrolyzing the matrix of the plant cell wall. These reactions disintegrate the cell wall and increase cell permeability. Enzymatic extraction depends on the concentration of the enzyme, reaction temperature, time, the particle size of the plant material, and type of enzyme [78]. The enzymatic extraction of pectin is carried out by pectinases which are enzymes mainly extracted from fungi. Pectinase is a generic term designating several enzymes species, including esterases (pectin methyl esterases), hydrolases (endo- and exopolygalacturonases), and lyase (pectine lyases). The enzymatic treatment interferes with the glycosidic bonds of the pectin and ensures their breakage. This action decreases the viscosity of the solution, facilitating filtration and centrifugation. This extraction method has the advantage of being less polluting than the previous ones. Additionally, pectinases have specific reactivity to pectin. However, enzymatic production remains expensive and the reaction is difficult to control. Finally, this method can lead to a degradation of the pectin and a loss of its properties [79]. In this method, cellulase, protease, alcalase, hemicellulase, pectin lyase, xylanase, $\alpha$-amylase, protease (such as Neutrase from Novozymes), $\beta$-glucosidase, endo- and exopolygalacturonase, 
and pectinesterase are most commonly used [1]. Table 2 summarizes the physico-chemical properties of pectins extracted by green methods, including enzymatic extraction.

\subsubsection{Ultrasonic-Assisted Extraction}

Ultrasounds (Us) have been widely used in the food industry for their chemical and/or physical effects. There are a large number of potential applications of Us in the food industry, without going into excessive detail, such as extraction emulsification, filtration, cutting, or food preservation [80]. Ultrasonic waves, ranging from 20 to $100 \mathrm{kHz}$, are often used in U-assisted extraction [81,82]. Ultrasonic-assisted extraction is a method used to reduce extraction time and increase yield compared to conventional methods (hydrolysis in an acid medium). In this method, sound waves pass through a liquid medium, creating compression and expansion. This process leads to cavitation, that is, the production, growth, and collapse of bubbles [83]. This causes the formation of unstable microscopic bubbles which have high temperatures and pressures. Cavitation takes place near the surface of the target material. As a result, it affects the plant matrix and allows better penetration of the extractor solvents $[49,84]$ and, therefore, extraction efficiency is better.

Significant benefits of U-assisted extraction are reduced extraction time, equipment size, and energy consumption, and improved extraction yield, and it is considered more environmentally friendly than the conventional method. In contrast, U-extracted polysaccharides have lower viscosity, molecular mass, and degree of esterification [34,85].

The main parameters of $U$ treatment in the food industry involve frequency and intensity of sound waves, sonication time, solvent type, and temperature [86]. U frequency affects the extraction process since it affects microbubble size and resistance to mass transfer. An increase in $U$ frequency leads to a reduction in the production and intensity of cavitation in liquid [81]. The intensity of Us is an important extraction factor. Increased intensity of Us was reported to enhance pectin extractability by disrupting plant cells, thereby improving pectin yield [49]. However, it was also pointed out that high power intensity might produce the opposite effect, i.e., a decrease in pectin yield. Therefore, optimization of ultrasonic variables is very important. The extraction efficiency of $U$ in combination with other technologies such as microwave heating (UMAE and MUAE) can be significantly increased [87]. Table 2 summarizes the physico-chemical properties of pectins extracted by green methods, including UAE.

\subsubsection{Dielectric Barrier Discharge Plasma Extraction (DBD)}

Plasma, the fourth state of matter, involves partially ionized gases containing reactive species such as negative and positive ions, electrons, gas atoms, free radicals, and photons. Dielectric barrier discharge (DBD), radiofrequency, gliding arc discharge, and corona discharge are methods that generate atmospheric cold plasma [88]. DBD can modify the biomacromolecule's side chains through the action of the chemically active species constituting the plasma or break down specific bonds for the destruction of the secondary structure [89]. DBD can also be used to degrade biopolymers, including proteins and polysaccharides. The hydroxyl free radicals produced by high-energy electrons from the DBD process attack the pectin chains and degrade them into molecules of smaller sizes [36]. Pectin extraction by DBD plasma has not attracted much attention and there is limited research on this topic. DBD may also be used to modify pectin structure in the future.

\section{Commercial Pectins}

Commercial pectins are extracted from citrus (lemon, lime, orange) peels (85.5\%), apple pomace $(14.0 \%)$, and sugar beet pulp $(0.5 \%)$ by acid extraction at $\mathrm{pH} 1.5-3.0$ with conventional heating techniques $\left(60-100^{\circ} \mathrm{C}\right)$ for several hours $[2,90]$. The pectin product is $\mathrm{HM}$ pectin with a size range of $7-14 \times 10^{4} \mathrm{Da}$ [26]. However, pectin yield and the physicochemical characteristics of recovered pectin depend on the extraction methods used and other parameters, such as $\mathrm{pH}$, extraction acid, temperature, extraction time, and liquidsolid ratios. Apple pomace and citrus peels are available in large amounts as by-products 
of the fruit juice and essential oil industry, whereas sugar beet pulp is obtained from the sugar industry. While citrus peel contains $20-30 \%$ pectin on a dry matter basis, apple pomace contains 10-15\%. Recently, much research has been carried out to extract pectin from alternative sources. Interestingly, the rinds of watermelon, a tropical/subtropical fruit, also have high pectin contents (13-30\%) and the recorded yield of pectin reached $28 \%$. These figures clearly illustrate the potential of tropical and subtropical fruit by-products for pectin extraction [2].

\section{Pectin from Watermelon}

Several studies have analyzed the pectin extracted from watermelon rind. The extraction of this pectin was carried out with conventional, enzymatic, and microwave-assisted extractions. Conventional extraction of watermelon rind using nitric acid, for $45 \mathrm{~min}$, $\mathrm{pH} 1.65$, with a solid to liquid ratio of $0.258 \mathrm{~g} / \mathrm{mL}$ using a water bath, has shown an extraction yield of $12 \%$. Moreover, pectin yield for enzymatic extraction of watermelon rind using Fibrilase and Multifect XL at solid to liquid ratios of 0.18 and $0.25 \mathrm{~g} / \mathrm{mL}$ using enzyme loadings of 4.6 and $3.0 \mathrm{FPU} / \mathrm{g}$, respectively, at $50{ }^{\circ} \mathrm{C}$ for $15 \mathrm{~h}$ in $50 \mathrm{mM}$ citrate buffer could reach $20 \%$. The highest galacturonic acid content was found using acid extraction ( 70\%) and all the pectins obtained were LM [91-93].

Extraction of pectin from watermelon by MAE, at a power of $500 \mathrm{~W}, \mathrm{pH}$ of 1.5, time of $7 \mathrm{~min}$, and a solid-liquid ratio of 1:20, led to yields between 19.1 and 19.6\%. The pectins extracted had DEs between 44.3 and 48.7\%, molecular weights between 143,400 and $154,300 \mathrm{Da}$, and GalA contents between 74.6 and 76.1\%. Yields of 17.4-17.6\%, ash content of $1.6-1.9 \%$, GalA contents of $78.3-82.8 \%$, DE of $38.2-41.2 \%$, and Mw of $110,600-128,000 \mathrm{Da}$ were reported for pectins extracted by $\mathrm{CHE}$. CHE was carried out in the following optimum conditions: $\mathrm{pH}$ of 1.0 , temperature of $90^{\circ} \mathrm{C}$, time of $150 \mathrm{~min}$, and solid-liquid ratio of $1: 20[70]$.

The effect of pretreatment (drying of watermelon rind) was evaluated by Petkowicz et al. (2017) [6]. They reported that the pectin obtained from fresh and lyophilized watermelon (FW and LW) rind has a high degree of methyl esterification (60\%). FW and LW were able to produce a lower dynamic surface tension and higher foaming ability than gum arabic at the same concentration. The viscosity of the FW sample was higher than that of LW sample despite their similar molar mass [6]. Maran et al. (2014) showed that the optimum conditions to obtain the maximum yield $(25.79 \%)$ of pectin is microwave power of 477 watts, time irradiation of $128 \mathrm{~s}$, with a pH of 1.52 [76]. Additionally, Rasheed et al. (2008) reported that the pectin extracted from watermelon peel with a yield of $15.19 \%$ was an LM pectin ( $\mathrm{DE}=44.3)$ [43]. Hartati et al. (2014) found that the optimum MAE conditions for the highest extraction yield of $11.25 \%$ were achieved with a 15 min extraction time in $0.5 \mathrm{M}$ sulfuric acid solution with a solid-liquid ratio of 1:08. The lower extraction yield observed for extraction with higher power could be due to pectin degradation, as reported previously [92]. The isolated pectins were HM pectins (DM higher than 50\%). These results contrast with those reported by Jiang et al. (2012). Indeed, only LM pectins were obtained from watermelon rind extractions by these authors [6]. Korish (2015) extracted pectin from Citrullus lanatus var. Colocynthoides (C. var. Colocynthoides), a wild type of watermelon, only cultivated for seeds. The highest yield $(19.75 \% w / w)$ was achieved using a solid-liquid ratio of 1:15, $\mathrm{pH} 2$, and $85^{\circ} \mathrm{C}$, for $60 \mathrm{~min}$. The galacturonic acid content and methylation degree of extracted pectin were 76.84 and $55.25 \%$, respectively. The neutral sugars of the extracted pectin were galactose $(9.07 \%$ ( $w / w$ of pectin $))$, followed by arabinose $(4.88 \%)$, rhamnose $(2.54 \%)$, glucose $(2.52 \%)$, mannose $(0.22 \%)$, and xylose $(0.56 \%)$ [93]. Watermelon rind can be considered as a valuable source of pectin because it contains a significant amount of this polysaccharide (Tables 1 and 2), although it is lower than that of citrus, the main commercial source of pectin. According Table 3 and Table 4, watermelon pectin can have emulsifying activity and good water-holding (WHC) and oil-holding $(\mathrm{OHC})$ capacities. 
Table 2. Extraction conditions and physico-chemical properties of pectin extracted by green methods from agricultural wastes, food by-products, and others.

\begin{tabular}{|c|c|c|c|c|c|c|c|c|c|c|c|c|c|}
\hline \multirow[b]{2}{*}{ Pectin Sources } & \multicolumn{8}{|c|}{ Extraction Conditions } & \multirow[b]{2}{*}{ Yields (\%) } & \multirow[b]{2}{*}{ DM (\%) } & \multirow[b]{2}{*}{ GalA (\%) } & \multirow[b]{2}{*}{$\underset{(\mathrm{kg} / \mathrm{mol})}{\mathrm{Mw}}$} & \multirow[b]{2}{*}{ References } \\
\hline & Treatments & Solvents & $\begin{array}{c}\text { Temperatures } \\
\left({ }^{\circ} \mathrm{C}\right)\end{array}$ & $\mathrm{pH}$ & $\mathrm{S} / \mathrm{L}$ & Times & $\begin{array}{l}\text { Power (w) or } p \\
\text { Intensity }(w / c m)\end{array}$ & $\begin{array}{c}\text { Enzyme } \\
\text { Treatments }\end{array}$ & & & & & \\
\hline Chicory root & EAE & $\begin{array}{l}\text { sodium } \\
\text { acetate } \\
\text { buffer }\end{array}$ & 50 & 5.5 & & $4 \mathrm{~h}$ & & $\begin{array}{l}\text { cellulase- } \\
\text { protease }\end{array}$ & - & 52 & 55 & 250 & [94] \\
\hline Lime peel & $\mathrm{EAE}$ & $\begin{array}{l}\text { citrate } \\
\text { buffer }\end{array}$ & 50 & 3.5 & $1: 30$ & $4 \mathrm{~h}$ & & $\begin{array}{l}\text { Laminex } \\
\text { C2K }\end{array}$ & 22.5 & 82.2 & & 115 & [94] \\
\hline Lime peel & EAE & $\begin{array}{l}\text { citrate } \\
\text { buffer }\end{array}$ & 50 & 3.5 & $1: 30$ & $4 \mathrm{~h}$ & & $\begin{array}{l}\text { Validase } \\
\text { TRL }\end{array}$ & 26.3 & 79.1 & & 225.5 & [94] \\
\hline Beetroot & $\mathrm{EAE}$ & $\begin{array}{l}\text { citrate } \\
\text { buffer }\end{array}$ & 30 & - & $1: 100$ & $20 \mathrm{~h}$ & & cellulase & - & 80 & 55 & 1309 & [95] \\
\hline Butternut squash & EAE & $\begin{array}{l}\text { citrate } \\
\text { buffer }\end{array}$ & - & - & $1: 100$ & $20 \mathrm{~h}$ & & cellulase & - & 2 & 54 & 136 & [95] \\
\hline Green tea leaf & EAE & $\mathrm{HCl}$ & 30 & 4.5 & - & $3 \mathrm{~h}$ & & Viscozyme & 8.5 & 22.4 & 27.1 & & {$[64]$} \\
\hline Green tea leaf & EAE & $\mathrm{HCl}$ & 30 & 4.5 & - & $3 \mathrm{~h}$ & & $\begin{array}{c}\text { FoodPro }^{\circledR} \\
\text { CBL }\end{array}$ & 5.1 & 40.9 & 26.6 & & [64] \\
\hline Prickly pear & UAE & - & 70 & 1.5 & $1: 30$ & $\begin{array}{c}70 \\
\min \end{array}$ & $330 \mathrm{~W}$ & & 18.14 & 41.4 & 68.87 & & [96] \\
\hline $\begin{array}{c}\text { Suaeda } \\
\text { fruticosaleaves }\end{array}$ & UAE & citric acid & 90 & 2.9 & $1: 30$ & $\begin{array}{c}37 \\
\min \end{array}$ & $140 \mathrm{~W}$ & & 34.0 & 33 & 47.5 & 229 & [97] \\
\hline $\begin{array}{l}\text { Pomegranate } \\
\text { peels }\end{array}$ & UAE & $\begin{array}{l}\text { citrate } \\
\text { buffer }\end{array}$ & - & 5 & $1: 15$ & $\begin{array}{c}20 \\
\min \end{array}$ & $150 \mathrm{~W}$ & & 24.8 & 68.5 & 72 & 146.5 & [98] \\
\hline Grapefruit & UAE & $\mathrm{HCl}$ & 70 & 1.5 & $1: 50$ & $\begin{array}{c}25 \\
\min \end{array}$ & - & & 17.92 & 75.1 & 68.21 & 68.3 & [75] \\
\hline Grapefruit peel & UAE & - & 67 & - & $1: 50$ & $\begin{array}{c}28 \\
\min \end{array}$ & $800 \mathrm{~W}$ & & - & 58.7 & 56.39 & 279.47 & [68] \\
\hline Grapefruit peel & UAE & $\mathrm{HCl}$ & 66.7 & 1.5 & $1: 50$ & $\begin{array}{l}27.9 \\
\min \end{array}$ & $12.56 \mathrm{~W} / \mathrm{cm} 2$ & & 27.46 & 65.5 & 50.03 & 109.5 & [49] \\
\hline Musa balbisiana & UAE & citric acid & & 3.2 & $1: 15$ & $\begin{array}{c}27 \\
\min \end{array}$ & $323 w$ & & 8.99 & & & & [99] \\
\hline Eggplant peel & UAE & citric acid & - & 1.5 & $1: 20$ & $\begin{array}{c}30 \\
\min \end{array}$ & $50 \mathrm{~W}$ & & 33.64 & 61.2 & 66.08 & & [100] \\
\hline
\end{tabular}


Table 2. Cont.

\begin{tabular}{|c|c|c|c|c|c|c|c|c|c|c|c|c|c|}
\hline \multirow[b]{2}{*}{ Pectin Sources } & \multicolumn{8}{|c|}{ Extraction Conditions } & \multirow[b]{2}{*}{ Yields (\%) } & \multirow[b]{2}{*}{ DM (\%) } & \multirow[b]{2}{*}{ GalA (\%) } & \multirow[b]{2}{*}{$\underset{(\mathrm{kg} / \mathrm{mol})}{\mathrm{Mw}}$} & \multirow[b]{2}{*}{ References } \\
\hline & Treatments & Solvents & $\begin{array}{c}\text { Temperatures } \\
\left({ }^{\circ} \mathrm{C}\right)\end{array}$ & $\mathrm{pH}$ & $\mathrm{S} / \mathrm{L}$ & Times & $\begin{array}{l}\text { Power (w) or p. } \\
\text { Intensity (w/cm) }\end{array}$ & $\begin{array}{c}\text { Enzyme } \\
\text { Treatments }\end{array}$ & & & & & \\
\hline Passionfruit peel & UAE & HNO3 & 85 & 2.0 & $1: 30$ & $\begin{array}{c}10 \\
\min \end{array}$ & $644 \mathrm{~W} / \mathrm{cm} 2$ & & 12.67 & 60.3 & 66.65 & & [101] \\
\hline Papaya powder & UAE & $\mathrm{HCl}$ & 60 & 2.0 & $1: 4$ & $\begin{array}{c}56 \\
\min \end{array}$ & 320 & & 2.61 & - & - & & [102] \\
\hline Apple peel waste & UAE & $\mathrm{HCl}$ & 63 & 2.36 & $1: 23$ & $\begin{array}{c}18 \\
\min \end{array}$ & $90 \mathrm{~W}$ & & 8.93 & 70 & 70.24 & 198.65 & [103] \\
\hline Apple pomace & MAE & $\mathrm{HCl}$ & - & 1.01 & $1: 14$ & $\begin{array}{l}20.8 \\
\mathrm{~min}\end{array}$ & $499.4 \mathrm{~W}$ & & 15.75 & - & - & - & [104] \\
\hline Dragon fruit & MAE & citric acid & 75 & 2.9 & $1: 56$ & $\begin{array}{c}12 \\
\min \end{array}$ & $183 \mathrm{~W}$ & & 17.01 & 45.0 & 60.10 & & [105] \\
\hline Jackfruit rinds & MAE & $\begin{array}{l}\text { distilled } \\
\text { water }\end{array}$ & - & - & $1: 25$ & $\begin{array}{c}10 \\
\min \end{array}$ & $600 \mathrm{~W}$ & & 17.63 & - & 70.29 & - & [69] \\
\hline Sweet lemon peel & MAE & citric acid & - & 1.5 & - & $3 \mathrm{~min}$ & $700 \mathrm{~W}$ & & 25.31 & 5.80 & 87.2 & 615.8 & [106] \\
\hline Grapefruit & MAE & $\mathrm{HCl}$ & - & - & $1: 50$ & $6 \mathrm{~min}$ & $900 \mathrm{~W}$ & & 27.81 & 80 & 75 & 50 & [75] \\
\hline Watermelon rinds & MAE & - & - & 1.52 & $1: 20$ & $128 \mathrm{~s}$ & $477 \mathrm{~W}$ & & 25.79 & - & - & - & [76] \\
\hline Watermelon peel & MAE & sulfuric acid & - & 1.5 & $1: 20$ & $7 \mathrm{~min}$ & $500 \mathrm{~W}$ & & 19.6 & 48.7 & 74.9 & 149.9 & [70] \\
\hline Watermelon rinds & MAE & acetic acid & - & 2 & $1: 100$ & $\begin{array}{c}12 \\
\min \end{array}$ & $279 \mathrm{~W}$ & & 5.76 & 56.8 & - & - & [8] \\
\hline Watermelon rind & MAE & sulfuric acid & - & - & $1: 10$ & $\begin{array}{l}15 \\
\min \end{array}$ & $39,9 \mathrm{~W}$ & & 18 & - & - & - & [108] \\
\hline Banana peels & MAE & $\mathrm{HCl}$ & - & 3.00 & $1: 50$ & $100 \mathrm{~s}$ & $900 \mathrm{~W}$ & & 2.18 & - & - & - & [109] \\
\hline Sour orange peel & MAE & citric acid & - & 1.50 & $1: 15$ & $3 \mathrm{~min}$ & $700 \mathrm{~W}$ & & 28.8 & 1.5 & 71.0 & - & [110] \\
\hline Pomelo peel & MAE & $\mathrm{NaOH}$ & - & - & $1: 30$ & $2 \mathrm{~min}$ & $1100 \mathrm{~W}$ & & 24.2 & - & 85.7 & 142 & [26] \\
\hline Pomelo peel & MAE & $\mathrm{HCl}$ & - & - & $1: 30$ & $2 \mathrm{~min}$ & $1100 \mathrm{~W}$ & & 20.5 & 71.2 & 85.0 & 327 & [26] \\
\hline $\begin{array}{c}\text { Pistachio green } \\
\text { hull }\end{array}$ & MAE & - & & 1.5 & $1: 15$ & $165 \mathrm{~s}$ & $700 \mathrm{~W}$ & - & 18.13 & 12.1 & 66.0 & 1659 & [111] \\
\hline Lime peel & MAE & $\mathrm{HCl}$ & & & $1: 40$ & & $700 \mathrm{~W}$ & - & 23.32 & 70.8 & 91.00 & 635.63 & [40] \\
\hline
\end{tabular}

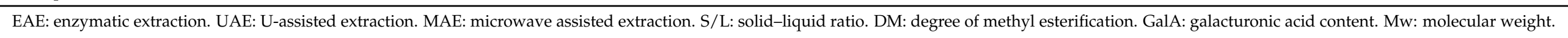




\section{Techno-Functional Properties and Application of Pectin}

\subsection{Pectin Gel}

A pectin gel is a three-dimensional network of macromolecules including a solvent. It is formed by physical or chemical changes that tend to decrease the solubility of pectin, promoting the formation of local crystallizations [10]. Physico-chemical and functional properties of pectins, such as gelling properties, are highly related to their structures, including their $\mathrm{Mw}, \mathrm{DE}$, GalA content, and monosaccharide composition, which depend on plant sources and extraction methods [26,40]. Regardless of their DM, pectin can form gels by different mechanisms. In the case of HM pectin, the higher the DM is, the faster the gel is formed. LM pectin is capable of forming gel by strongly binding divalent ions [72]. Commercial HM pectin (generally at $8-11 \%$ methoxyl content) are capable of forming a gel with a high sugar content $(>65 \%$ sugar) and acidic $\mathrm{pH}(2.20-2.80)[112,113]$. The low $\mathrm{pH}$ reduces the electrostatic repulsion and the sugar helps to bring the chains closer together and thus the establishment of hydrogen bonds due to the reduction in the water activity [114]. The pectin-water interaction is therefore favored by these two elements. The formation of the three-dimensional network is allowed in part because of the hydrophobic interactions existing between the methyl groups [115]. The formation of gel depends on the time, temperature, and the kind of sugar used [116]. LM pectin gel occurs when coordination bonds are formed between carboxylate groups (at the level of homogalacturonic unesterified zones) and divalent cations (calcium) [117]. The formation of pectin-calcium cation gels is characterized by the "egg box" model (Figure 5) [118]. LM pectins with less than $7 \%$ methoxyl content can form gels at a lower sugar content than HM pectins [119]. Therefore, the number of applications of LM pectins is larger and different to those of HM pectins.

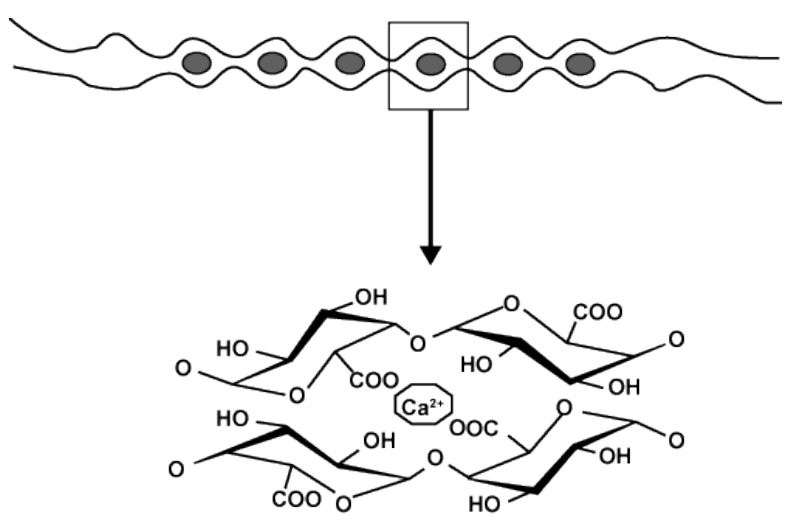

Figure 5. Gelation of LM pectins in the presence of $\mathrm{Ca}^{2+}$ cations.

Gels formed by high molecular weight pectins (typically $\mathrm{Mw} \geq 300 \mathrm{kDa}$ ) always have compact network structures with high mechanical strength, rupture strength, and viscosity [120]. Pectin with a low molecular weight $(\leq 10 \mathrm{kDa})$ was not able to form gels [14]. The methylation degree decreased gradually when increasing the acidity of extraction media and extraction time [40,93].

Galacturonic acid (GalA) residues of pectins dominate the cross-link between pectin and $\mathrm{Ca}^{2+}$ ions. Branched chains can negatively affect the gelation of pectin, inhibiting binding between pectin and $\mathrm{Ca}^{2+}$ [121]. The high percentage of GalA is essential for the formation of Ca-dependent gels with increased stability, mechanical strength, and water-holding capacity [122]. The Ca-dependent gelation of pectin and gel properties can also be affected by the inter- and intra-molecular distribution of non-methoxylated GalA blocks [123]. Compared to a random distribution, pectin with a block-wise distribution of non-methoxylated GalA blocks showed a better gelation ability and a stronger mechanical strength of the final gels $[123,124]$. The degree of methoxylation strongly affects Ca-pectin gel properties. Pectin with a low DM forms gels with high viscosity and hardness, because 
the methoxylated carboxyl groups in GalA units cannot bind $\mathrm{Ca}^{2+}$ as they are not negatively charged and, accordingly, affect the formation of the egg box structure and thus the gel mechanical properties $[124,125]$. The acetylation of GalA in pectin resulted in a reduced number of Ca-binding sites, which is unfavorable to the gel formation [123]. The acetyl groups were reported to strongly prevent the formation of dimers (Ca-pectinate) [126]. The concentration of pectin can significantly influence their gelation process and gel properties (e.g., viscosity, elasticity, hardness, strength, or rupture strength) [127]. As compared with low Mw, LM pectin with higher Mw, accordingly, has a longer molecular chain and thus more $\mathrm{Ca}^{2+}$-binding sites. A large number of active $\mathrm{Ca}^{2+}$-binding sites contributes to the formation of percolating network structures and improved rheological properties of the gels (faster formation kinetics, enhanced viscosities, and higher elastic modulus) [123]. Indeed, viscoelastic materials combine two different properties. The term "viscous" means that they deform when exposed to an external force, whereas the term "elastic" implies that once a deforming force has been removed, the material will return to its original configuration. The viscoelastic response of material is measured by complex moduli of elasticity $\left(G^{\prime}\right.$, the storage modulus and $\mathrm{G}^{\prime \prime}$, the elastic modulus). Watermelon pectin at $5 \%(w / v)$ showed a weak gel-like behavior with a typical shear thinning behavior. Petkowicz et al. (2017) showed that the elastic modulus was higher than the viscous modulus for watermelon pectin at $5 \%(w / v)$ over the analyzed frequency range and the moduli increased with increasing frequency. Therefore, this solution behaved as a weak gel. Negatively charged GalA and electrostatic interactions between positively charged side chains of the protein are responsible for this behavior of watermelon rind pectins. Furthermore, watermelon pectin had greater values of elastic modulus than those described for pectin obtained from apple pomace by enzymatic and chemical methods and from cacao pod husks using nitric acid [6].

\subsection{Water/Oil-Holding Capacity}

$\mathrm{OHC}$ or WHC of pectins is defined as the quantity of oil/water fixed by pectin after homogenization, incubation in the oil/water phase, and centrifugation. These quality parameters can be influenced by the hydrophobic/hydrophilic character of constituents and the total charge density [128]. WHC and OHC are two functional properties that are related to texture by the interaction between food product components [129]. OHC is an important feature of pectin in the food system because pectin with a high OHC can be used as a stabilizer or emulsifier in high-fat foods, such as some meat products. WHC depends on the hydration ability of pectin, which could be produced by the $\mathrm{OH}$ group in the structure. The high absorption of water by pectin makes it suitable for reducing the syneresis rate in some food products (e.g., yogurts, dairy desserts, etc.) [15]. The WHC and $\mathrm{OHC}$ of pectin extracted from watermelon rind are significantly higher than those of commercial gluten [129]. The WHC and OHC of different pectins are shown in Table 3.

Table 3. Water-holding capacity (WHC) and oil-holding capacity $(\mathrm{OHC})$ of pectin extracted from various sources.

\begin{tabular}{|c|c|c|c|c|}
\hline Pectin Sources & Measurement Conditions & WHC & $\mathrm{OHC}$ & References \\
\hline $\begin{array}{l}\text { Sunflower stalk } \\
\text { pith }\end{array}$ & $\begin{array}{l}0.1 \mathrm{~g} \text { powder } / 6.0 \mathrm{~g} \text { deionized water } \\
\text { mixing for } 1 \mathrm{~min} \\
\text { incubating at room temperature for } 30 \mathrm{~min} \\
\text { centrifuging at } 9000 \times g \text { for } 30 \mathrm{~min}\end{array}$ & $\begin{array}{c}40.2 \mathrm{~g} \text { water } / \mathrm{g} \\
\text { powder }\end{array}$ & $40.4 \mathrm{~g}$ oil/g powder & [130] \\
\hline Tomato pomace & $\begin{array}{l}1 \mathrm{~g} \text { powder } / 20 \mathrm{~mL} \text { deionized water } \\
\text { mixing for } 1 \mathrm{~min} \\
\text { incubating at room temperature for } 60 \mathrm{~min} \\
\text { centrifuging at } 4000 \times \mathrm{g} \text { for } 30 \mathrm{~min}\end{array}$ & $\begin{array}{c}3.57 \mathrm{~g} \text { water } / \mathrm{g} \\
\text { powder }\end{array}$ & $2.65 \mathrm{~g}$ oil/g powder & [131] \\
\hline Eggplant & $\begin{array}{l}0.5 \mathrm{~g} \text { powder } / 50 \mathrm{~mL} \text { deionized water } \\
\text { incubating at room temperature for } 60 \mathrm{~min} \\
\text { centrifuging at } 5000 \times \mathrm{g} \text { for } 20 \mathrm{~min}\end{array}$ & $\begin{array}{c}6.02 \mathrm{~g} \text { water } / \mathrm{g} \\
\text { powder }\end{array}$ & $2.6 \mathrm{~g}$ oil/g powder & [100] \\
\hline
\end{tabular}


Table 3. Cont.

\begin{tabular}{|c|c|c|c|c|}
\hline Pectin Sources & Measurement Conditions & WHC & OHC & References \\
\hline Walnut & $\begin{array}{l}1 \mathrm{~g} \text { powder } / 10 \mathrm{~mL} \text { deionized water } \\
\text { mixing for } 1 \mathrm{~min} \\
\text { centrifuging at } 3000 \times \mathrm{g} \text { for } 20 \mathrm{~min}\end{array}$ & $\begin{array}{l}5.84 \mathrm{~g} \text { water } / \mathrm{g} \\
\text { powder }\end{array}$ & $2.22 \mathrm{~g}$ oil $/ \mathrm{g}$ powder & [132] \\
\hline $\begin{array}{l}\text { Commercial apple } \\
\text { pectin }\end{array}$ & $\begin{array}{l}1 \mathrm{~g} \text { powder } / 60 \mathrm{~mL} \text { deionized water } \\
\text { incubating at room temperature for } 24 \mathrm{~h} \\
\text { centrifuging at } 14,000 \times \mathrm{g} \text { for } 1 \mathrm{~h}\end{array}$ & $\begin{array}{l}2.00 \mathrm{~g} \text { water } / \mathrm{g} \\
\text { powder }\end{array}$ & $2.22 \mathrm{~g}$ oil $/ \mathrm{g}$ powder & [133] \\
\hline $\begin{array}{l}\text { Commercial citrus } \\
\text { pectin }\end{array}$ & $\begin{array}{l}1 \mathrm{~g} \text { powder } / 60 \mathrm{~mL} \text { deionized water } \\
\text { incubating at room temperature for } 24 \mathrm{~h} \\
\text { centrifuging at } 14,000 \times \mathrm{g} \text { for } 1 \mathrm{~h}\end{array}$ & $\begin{array}{c}10.00 \mathrm{~g} \text { water } / \mathrm{g} \\
\text { powder }\end{array}$ & $2.59 \mathrm{~g}$ oil/g powder & [133] \\
\hline $\begin{array}{l}\text { By-product from } \\
\text { olive oil production }\end{array}$ & $\begin{array}{l}1 \mathrm{~g} \text { powder } / 60 \mathrm{~mL} \text { deionized water } \\
\text { incubating at room temperature for } 24 \mathrm{~h} \\
\text { centrifuging at } 14,000 \times g \text { for } 1 \mathrm{~h}\end{array}$ & $\begin{array}{l}1.87 \mathrm{~g} \text { water } / \mathrm{g} \\
\text { powder }\end{array}$ & $6.17 \mathrm{~g}$ oil $/ \mathrm{g}$ powder & [133] \\
\hline Pistachio green hull & $\begin{array}{l}1 \mathrm{~g} \text { powder } / 10 \mathrm{~mL} \text { deionized water } \\
\text { mixing for } 1 \mathrm{~min} \\
\text { centrifuging at } 3000 \times \mathrm{g} \text { for } 30 \mathrm{~min}\end{array}$ & $\begin{array}{l}4.11 \mathrm{~g} \text { water } / \mathrm{g} \\
\text { powder }\end{array}$ & $2.02 \mathrm{~g}$ oil $/ \mathrm{g}$ powder & [111] \\
\hline Opuntia ficus indica & $\begin{array}{l}0.5 \mathrm{~g} \text { powder } / 50 \mathrm{~mL} \text { deionized water } \\
\text { incubating at room temperature for } 60 \mathrm{~min} \\
\text { centrifuging at } 5000 \times \mathrm{g} \text { for } 20 \mathrm{~min}\end{array}$ & $\begin{array}{l}4.84 \mathrm{~g} \text { water } / \mathrm{g} \\
\text { powder }\end{array}$ & $1.01 \mathrm{~g}$ oil $/ \mathrm{g}$ powder & [96] \\
\hline Watermelon rind & $\begin{array}{l}0.5 \mathrm{~g} \text { powder } / 50 \mathrm{~mL} \text { deionized water } \\
\text { incubating at room temperature for } 60 \mathrm{~min} \\
\text { centrifuging at } 15,025 \times g \text { for } 20 \mathrm{~min}\end{array}$ & $\begin{array}{l}2 \text { g water /g } \\
\text { powder }\end{array}$ & $4 \mathrm{~g}$ oil/g powder & [129] \\
\hline
\end{tabular}

WHC: water-holding capacity, OHC: oil-holding capacity.

\subsection{Emulsion}

Oil-in-water $(o / w)$ emulsions are interesting delivery systems of lipophilic bioactive compounds, such as vitamins and antioxidants [134]. These emulsions are thermodynamically unstable systems, consisting of dispersed oil droplets in a continuous, aqueous phase. Emulsifiers are often added to kinetically stabilize $o / w$ emulsions. The type of emulsifiers used depends on the product shelf life, functionality, and stability. In the emulsification process, the emulsifier adsorbs at the surface of the fine droplets, which is created by mechanical homogenization, and protects them from coalescing with neighboring drops by forming a steric stabilizing layer. The most commonly used types of emulsifier in the food industry are small-molecule surfactants, biopolymers, and phospholipids [135]. Emulsifying activity (EA) and emulsion stability (ES) are two parameters used to characterize an emulsion. They are defined, respectively, as the maximum amount of oil that can be emulsified by a fixed amount of the emulsifying agent and as the rate of phase separation of water and oil during storage of the emulsion.

Good emulsion stability means that the size distribution and the spatial arrangement of droplets do not change significantly during the observation time. Rheological properties of food emulsions play an important role in the stability as well as in the mouthfeel and texture of these products [136]. Pectin has been introduced as an emulsion-stabilizing agent, mainly by increasing the viscosity of the continuous phase [137]. A high viscosity of the aqueous continuous phase can reduce oil droplet coalescence and flocculation [137]. The ability of pectin to increase the viscosity of the aqueous phase is partly caused by its HG domain. The contribution of HG to emulsion stabilization might be dependent on the HG/RG-I ratio [138]. Therefore, HG-rich pectins reveal higher solution viscosity, as compared to RG-I-rich pectins [118]. The amount and pattern of distribution of hydrophilic and hydrophobic groups in pectin determine the solubility and rheological properties of liquid food products to which pectin has been added. Different extraction methods lead to the production of pectins that ultimately produce different viscosities in aqueous solution, affecting emulsion characteristics [77]. Additionally, the presence of high hydrophobicity 
of the protein moieties linked to the arabinogalactan part of pectin and its methyl, acetyl, and ferulic acid ester contents provide the ability to adsorb at the oil-water interface [135]. These compounds play a role in the initial stage of emulsion formation, while the next stage is emulsion stabilization. Therefore, according to previous studies, pectin structural features and conformation of the carbohydrate domain are the main factors limiting or preventing emulsion instability $[137,139]$. The carbohydrate domain creates the stereo and electrostatic effects stabilizing simple emulsions. RG-I and HG domains contribute to the steric and electrostatic effects, respectively. It has been hypothesized that the RG-I generates thick adsorbed hydrated layers, which prevent droplets from coalescing. Moreover, neutral side chains are possibly related to their interactions with ferulic acid and/or proteins can contribute to emulsion stabilization. The non-esterified GalA units can form a charged stabilizing layer $[6,125]$. The pectin charge, which affects emulsion stability, was strongly dependent on its $\mathrm{DM}$ and the $\mathrm{pH}$ of the aqueous phase $[135,140]$ and it may confer a negative charge $(\mathrm{pH}>\sim 3.5)$ in the surrounding areas of oil droplets due to its anionic nature (carboxylic groups), contributing to the electrostatic stability of $o / w$ emulsions [118] The emulsifying and emulsion-stabilizing properties of pectins extracted from various sources are shown in Table 4. Among the commercial pectins, those from citrus peel and apple pomace are not considered as effective emulsifying agents, contrary to those from sugar beet [141]. The origin of these different behaviors is mainly attributed to the higher protein and ferulic acid contents in the latter [142]. Yang et al. (2018) showed that the emulsion activities (EAs, 44.97-47.71\%) and emulsion stabilities (ESs, 36.54-46.00\%) of potato pectins were affected by various acids in extraction and were higher than commercial citrus and apple pectins [39].

The pectins extracted from watermelon produced lower dynamic surface tension than gum arabic, which is well known for its emulsifying properties [6]. The surface area moment mean (Sauter mean diameter- $\mathrm{D}_{[3,2]}$ ) and the volume moment mean (De Brouckere mean diameter- $\left.-\mathrm{D}_{[4,3]}\right)$ show the sizes of colloidal particles, based on distribution moments. $D_{[3,2]}$ is most sensitive to the presence of fine particles in size distribution whereas $D_{[4,3]}$ is most sensitive to the presence of large particles. Values of $D_{[3,2]}$ and $D_{[4,3]}$ obtained for emulsions prepared with watermelon pectin were similar to those collected for emulsions made with gum arabic [6].

Table 4. Emulsifying and emulsion-stabilizing properties of pectins extracted from various sources.

\begin{tabular}{|c|c|c|c|}
\hline Sources & Process Conditions & Emulsion-Based Characteristics & References \\
\hline Beet pectin & $\begin{array}{c}\text { pH } 7.0 \\
\text { oil phase: } 10 \mathrm{wt} \% \\
\text { homogenization pressures } \\
(9-19) \mathrm{kpsi}\end{array}$ & $\begin{array}{l}\text { the reduction in surface tension reported is as follows: } \\
\text { gum arabic } \geq \text { beet pectin } \\
\text { emulsions could not be prepared using beet pectin at } \\
\text { concentrations greater than } 2 \mathrm{wt} \% \\
\text { the minimum } \mathrm{D}_{[4,3]} \text { at } 1 \% \text { beet pectin is lower than that } \\
\text { obtained with } 3 \% \text { gum arabic }\end{array}$ & [143] \\
\hline $\begin{array}{c}\text { Pomegranate } \\
\text { peel }\end{array}$ & $\begin{array}{l}\text { oil phase: } 50 \mathrm{wt} \% \\
\text { homogenization at } 20,000 \mathrm{rpm} \\
\text { for } 90 \mathrm{~s} .\end{array}$ & $\begin{array}{l}\text { pomegranate pectin cannot effectively reduce } \\
\text { surface tension } \\
\text { after incubation of the fresh emulsion at } 80^{\circ} \mathrm{C} \text { for } 1 \mathrm{~h} \text {, the } \\
\text { emulsion stability was } 96.7 \% \text {, at pectin concentration } \\
\text { of } 2.0 \%\end{array}$ & [66] \\
\hline Cauliflower & $\begin{array}{c}\text { pH } 3.8 \\
\text { oil phase: } 10 \mathrm{wt} \% \\
\text { homogenization: } 800,000 \mathrm{rpm} \\
\text { at room temperature } 1 \mathrm{~min} \\
\text { and followed by ultrasonic } \\
\text { wave probe }(3 \mathrm{~min})\end{array}$ & $\begin{array}{l}\text { cauliflower pectin was able to reduce surface tension from } \\
28 \mathrm{mN} / \mathrm{m} \text { (citrate buffer, } \mathrm{pH} 3.8) \text { to } 12 \mathrm{mN} / \mathrm{m}(0.5 \mathrm{wt} \% \\
\text { pectin solution) } \\
\text { the presence of acetyl groups and proteins in the sample } \\
\text { was most likely responsible for its emulsifying properties }\end{array}$ & [144] \\
\hline
\end{tabular}


Table 4. Cont.

\begin{tabular}{|c|c|c|c|}
\hline Sources & Process Conditions & Emulsion-Based Characteristics & References \\
\hline $\begin{array}{l}\text { Chicory root } \\
\text { pulp }\end{array}$ & $\begin{array}{c}\text { pH } 3.5 \\
\text { oil phase: } 15 \mathrm{wt} \% \\
\text { homogenization: } 20,000 \mathrm{rpm} \\
\text { for } 2 \text { min and followed by } \\
\text { ultrasonic wave at } 300 \mathrm{~W} \text { and } \\
2 \mathrm{~min}\end{array}$ & $\begin{array}{l}\text { the minimum } \mathrm{D}_{[3,2]} \text { values for chicory root pulp pectin } \\
(\mathrm{CRP})(0.58 \mu \mathrm{m}) \text { and sugar beet pectin }(0.54 \mu \mathrm{m}) \text { were } \\
\text { obtained at critical concentrations of } 1.5 \% \text { and } \\
22 \% \text {, respectively } \\
\text { CRP was shown to behave like SBP in the fabrication of } \\
\text { emulsions of small droplet sizes } \\
\text { CRP reduced interfacial tensions ( } 19 \text { from } 42 \mathrm{mN} / \mathrm{cm}) \\
\text { CRP may reach its maximum emulsification capacity at a } \\
\text { concentration of } 1.5 \%\end{array}$ & {$[63]$} \\
\hline Beetroot & $\begin{array}{c}\text { oil phase: } 20 \mathrm{wt} \% \\
\text { homogenization at } 24,000 \mathrm{rpm}\end{array}$ & $\begin{array}{l}\text { beetroot pectin (BRP) gave a lower surface tension than } \\
\text { gum arabic } \\
\text { the minimum } \mathrm{D}_{[3,2]} \text { of emulsion was obtained with a BRP } \\
\text { concentration of } 4 \%(w / w) \\
\text { BRP had smaller droplets than emulsion in the first } 10 \\
\text { days, and no difference in final droplet size was reported } \\
\text { between BRP and gum arabic }\end{array}$ & [145] \\
\hline Watermelon rind & $\begin{array}{l}\text { oil phase: } 10 \mathrm{wt} \% \\
\text { homogenization at } 24,000 \mathrm{rpm} \\
\text { for } 4 \mathrm{~min}\end{array}$ & $\begin{array}{c}\mathrm{D}_{[3,2]} \text { and } \mathrm{D}_{[4,3]} \text { obtained for emulsions prepared with } \\
\text { pectin of watermelon rind were similar to those obtained } \\
\text { with gum arabic } \\
\text { pectin of watermelon rind gave rise to a lower dynamic } \\
\text { surface tension than gum arabic }\end{array}$ & {$[6]$} \\
\hline Potato pulp & $\begin{array}{c}\text { oil phase: } 50 \mathrm{wt} \% \text { - } \\
0.5 \% \text { w/w of pectin solution } \\
\text { homogenization at } 10,000 \mathrm{rpm} \\
\text { for } 3 \mathrm{~min}\end{array}$ & $\begin{array}{l}\text { the emulsifying activity of potato pulp (PP) pectins } \\
\text { extracted by } \mathrm{HCl}(47.71 \%) \text { is higher than those of } \\
\text { commercial citrus }(44.87 \%) \text { and apple }(45.34 \%) \text { pectins }\end{array}$ & [39] \\
\hline $\begin{array}{l}\text { Pistachio green } \\
\text { hull }\end{array}$ & $\begin{array}{l}\text { oil phase: } 50 \mathrm{wt} \%- \\
0.5 \% w / w \text { of pectin solution } \\
\text { homogenization at } 10,000 \mathrm{~g} \\
\text { for } 4 \mathrm{~min}\end{array}$ & $\begin{array}{c}\text { the emulsifying activity of pistachio green hull pectin } \\
(58.3 \%) \text { was higher than pectins from Citrus medica peel } \\
(46.5 \%) \text { and sour orange peel }(40.7 \%) \\
\text { After } 30 \text { days, the emulsion stability was } 87.9 \% \text { and } 88.6 \% \\
\text { at } 4{ }^{\circ} \mathrm{C} \text { and } 24{ }^{\circ} \mathrm{C} \text {, respectively } \\
\text { surface tension of pistachio green hull pectin solutions } \\
\text { was } 46.23 \pm 0.32 \mathrm{mN} / \mathrm{m} \text { at concentration of } 0.5 \% \mathrm{w} / \mathrm{v} ; \\
\text { these values were lower than the data obtained from } \\
\text { sugar beet pulp }\end{array}$ & [111] \\
\hline
\end{tabular}

Reducing surface tension resulted in increased emulsion stability and emulsifying activity: $(a / b) * 100$ where a $=$ the volume of emulsion layer after centrifuging, $\mathrm{b}=$ the total volume of the system. The emulsion stability is calculated by the same method, after a period of time.

\section{Pectin Applications}

The major application of pectin is as a textural ingredient in food systems, while it is also used in cosmetics and personal care products [146]. In the pharmaceutical industry, pectin is used in the formulation of controlled-release matrix tablets, for example, as a carrier material in colon-targeted drug delivery. Due to the multifunctional properties of pectins, they have valuable applications in food industries as thickeners [147,148], stabilizers $[10,50,117]$, and emulsifiers [93]. Pectins can form a structural network and a viscoelastic solution and are widely used in jellies, marmalades, and jams. Pectins exhibit high viscosity and strong shear thinning behavior. These shear-thinning characteristics become more pronounced with increasing concentrations [149]. These different levels of viscosities could be attributed to the different macromolecular compositions of the samples [58,150]. The extraction method or additional processing can alter the rheology of pectin solutions. Pectins extracted with Us treatment give a more elastic solution. This may be due to the reduction in the DE and the side chains of apple pectin treated by Us [151].

The different properties of pectin, depending on its source or processing, lead to specific applications. For example, apple pectin is darker and has the property of being more viscous in solution compared to pectins from other sources. It is therefore more 
suitable for fillings and pastries. In contrast, citrus pectin is lighter and therefore more suited as a texturing agent for jam and confectionery jellies. In addition, the pectin structure can affect its application. HM pectin can be used as a gelling agent, stabilizer, emulsifier, and thickener in the food industry for the production of jams and jellies, while LM pectin can be used as a fat replacer in spreads, ice cream, fruit preparations for yoghurt, heatreversible bakery glazing, emulsified meat, or low-calorie products such as diet carbonated beverages [1]. The texture and stability of milk-based products can be modified by the addition of pectin [31]. Indeed, the gelling and thickening properties of pectins stabilize beverages containing acidified milk (dessert creams based on acid and non-acidic milk). Moreover, HM pectin can specifically stabilize acid casein particles, through HM pectincasein interactions, in acidified dairy beverages. The pectin acts in this case as a deflocculant and stabilizes the caseins by steric hindrance. In the presence of pectin, the particles no longer aggregate, and the formation of sediment is avoided. Pectin can also be used to stabilize cloudy beverages [152]. The stabilizing property of pectin prevents the separation of a heterogeneous medium (ice cream mix, preparation of fruit with pieces, cocoa drinks, etc.) and can be explained by the increasing viscosity and a network that is efficient enough to keep particles in suspension but weak enough not to be perceptible (gel liquids). The addition of pectin to a complex product such as jam can alter the perception of flavor, which varies depending on the type of pectin and aroma. The use of HM pectin decreases the olfactory intensity. The intrinsic viscosity, which indicates the hydrodynamic volume occupied by the polymer under given conditions, is a characteristic that represents the thickening power of pectin. This intrinsic viscosity of pectin is influenced by DM (related to molecular weight). The thickening power also depends on extrinsic conditions (temperature, type of solvent, $\mathrm{pH}$ ) [50,153]. Pectin can be used in emulsion-based foods such as low-fat mayonnaise and dressings, low-fat dairy products which emulate some characteristics of whole milk products and other beverages, emulsified meat products, and low-fat spreads [138].

\section{Conclusions}

Pectin has applications as a gelling, thickening, stabilizing, and emulsifying agent. Today, its application goes beyond the food industry and it has various applications in the medical and pharmaceutical industries. The functional properties of pectin are influenced by the source, methods, and conditions of extraction, mainly extraction time, $\mathrm{pH}$, solid/liquid, temperature, power and frequency of waves, type of enzymes used, and combinations of these factors. Novel extraction methods can reduce extraction time and solvent consumption and increase process efficiency and pectin yield. The composition of watermelon rind components, such as pectin and citrulline, suggests it as a valuable by-product instead of waste. Watermelon rind can be considered as a source of pectin because it contains a relatively significant amount of pectin, although its pectin content is lower than that of citrus, a commercial source of pectin. The pectin of watermelon rind demonstrates significant water/oil-holding capacity and promising emulsifying properties. Therefore, it could be used as a textural ingredient and emulsifier in food products and pharmaceutical supplements.

Author Contributions: N.H., G.D. and P.M.; validation, A.B., A.F., A.V.U., P.D., C.D. and G.P.; investigation, A.B., A.F. and A.V.U.; writing—original draft preparation, A.B., A.F., N.H. and P.M.; writing-review and editing, G.P., C.D., P.D., S.A., G.D. and P.M.; visualization, A.B., A.F., A.V.U., P.D., C.D., P.M., N.H., G.D., S.A. and G.P.; investigation, A.B. and A.F.; supervision, N.H., G.D. and P.M.; project administration, P.M. and N.H.; funding acquisition, N.H. and P.M. All authors have read and agreed to the published version of the manuscript.

Funding: This work was funded by the Hubert Curien Program PHC Gundishapur (45069SL).

Institutional Review Board Statement: Not applicable.

Informed Consent Statement: Not applicable. 


\section{Data Availability Statement: Not applicable.}

Conflicts of Interest: The authors declare no conflict of interest.

\section{References}

1. Marić, M.; Grassino, A.N.; Zhu, Z.; Barba, F.J.; Brnčić, M.; Brnčić, S.R. An overview of the traditional and innovative approaches for pectin extraction from plant food wastes and by-products: Ultrasound-, microwaves-, and enzyme-assisted extraction. Trends Food Sci. Technol. 2018, 76, 28-37. [CrossRef]

2. Picot-Allain, M.C.N.; Ramasawmy, B.; Emmambux, M.N. Extraction, characterisation, and application of pectin from tropical and sub-tropical fruits: A review. Food Rev. Int. 2020, 1-31. [CrossRef]

3. Naqash, F.; Masoodi, F.; Rather, S.A.; Wani, S.; Gani, A. Emerging concepts in the nutraceutical and functional properties of pectin-A Review. Carbohydr. Polym. 2017, 168, 227-239. [CrossRef]

4. Tlili, I.; Hdider, C.; Lenucci, M.S.; Riadh, I.; Jebari, H.; Dalessandro, G. Bioactive compounds and antioxidant activities of different watermelon (Citrullus lanatus (Thunb.) Mansfeld) cultivars as affected by fruit sampling area. J. Food Compos. Anal. 2011, 24, 307-314. [CrossRef]

5. Rimando, A.M.; Perkins-Veazie, P.M. Determination of citrulline in watermelon rind. J. Chromatogr. A 2005, 1078, 196-200. [CrossRef]

6. Petkowicz, C.; Vriesmann, L.; Williams, P. Pectins from food waste: Extraction, characterization and properties of watermelon rind pectin. Food Hydrocoll. 2017, 65, 57-67. [CrossRef]

7. Al-Sayed, H.M.; Ahmed, A.R. Utilization of watermelon rinds and sharlyn melon peels as a natural source of dietary fiber and antioxidants in cake. Ann. Agric. Sci. 2013, 58, 83-95. [CrossRef]

8. Sari, A.; Ishartani, D.; Dewanty, P. Effects of microwave power and irradiation time on pectin extraction from watermelon rinds (Citrullus lanatus) with acetic acid using microwave assisted extraction method. In Proceedings of the IOP Conference Series: Earth and Environmental Science, Semarang, Indonesia, 26-27 September 2017; p. 012085.

9. Jarvis, M.C. Structure and properties of pectin gels in plant cell walls. Plant Cell Environ. 1984, 7, 153-164.

10. May, C.D. Industrial pectins: Sources, production and applications. Carbohydr. Polym. 1990, 12, 79-99. [CrossRef]

11. Williams, P.A. Renewable Resources for Functional Polymers and Biomaterials: Polysaccharides, Proteins and Polyesters; The Royal Society of Chemistry: London, UK, 2011.

12. Olano-Martin, E.; Gibson, G.R.; Rastall, R. Comparison of the in vitro bifidogenic properties of pectins and pectic-oligosaccharides. J. Appl. Microbiol. 2002, 93, 505-511. [CrossRef] [PubMed]

13. do Nascimento Oliveira, A.; de Almeida Paula, D.; de Oliveira, E.B.; Saraiva, S.H.; Stringheta, P.C.; Ramos, A.M. Optimization of pectin extraction from Ubá mango peel through surface response methodology. Int. J. Biol. Macromol. 2018, 113, 395-402. [CrossRef]

14. Capel, F.; Nicolai, T.; Durand, D.; Boulenguer, P.; Langendorff, V. Influence of chain length and polymer concentration on the gelation of (amidated) low-methoxyl pectin induced by calcium. Biomacromolecules 2005, 6, 2954-2960. [CrossRef] [PubMed]

15. Khedmat, L.; Izadi, A.; Mofid, V.; Mojtahedi, S.Y. Recent advances in extracting pectin by single and combined ultrasound techniques: A review of techno-functional and bioactive health-promoting aspects. Carbohydr. Polym. 2020, 229, 115474. [CrossRef]

16. Beukema, M.; Faas, M.M.; de Vos, P. The effects of different dietary fiber pectin structures on the gastrointestinal immune barrier: Impact via gut microbiota and direct effects on immune cells. Exp. Mol. Med. 2020, 52, 1364-1376. [CrossRef] [PubMed]

17. Mellinas, C.; Ramos, M.; Jiménez, A.; Garrigós, M.C. Recent trends in the use of pectin from agro-waste residues as a natural-based biopolymer for food packaging applications. Materials 2020, 13, 673. [CrossRef]

18. Mohnen, D. Pectin structure and biosynthesis. Curr. Opin. Plant Biol. 2008, 11, 266-277. [CrossRef]

19. Jackson, C.L.; Dreaden, T.M.; Theobald, L.K.; Tran, N.M.; Beal, T.L.; Eid, M.; Gao, M.Y.; Shirley, R.B.; Stoffel, M.T.; Kumar, M.V. Pectin induces apoptosis in human prostate cancer cells: Correlation of apoptotic function with pectin structure. Glycobiol. 2007, 17, 805-819. [CrossRef]

20. Ralet, M.-C.; Cabrera, J.C.; Bonnin, E.; Quéméner, B.; Hellìn, P.; Thibault, J.-F. Mapping sugar beet pectin acetylation pattern. Phytochemistry 2005, 66, 1832-1843. [CrossRef]

21. Wang, W.; Chen, W.; Zou, M.; Lv, R.; Wang, D.; Hou, F.; Feng, H.; Ma, X.; Zhong, J.; Ding, T. Applications of power ultrasound in oriented modification and degradation of pectin: A review. J. Food Eng. 2018, 234, 98-107. [CrossRef]

22. Bonnin, E.; Saulnier, L.; Brunel, M.; Marot, C.; Lesage-Meessen, L.; Asther, M.; Thibault, J.-F. Release of ferulic acid from agroindustrial by-products by the cell wall-degrading enzymes produced by Aspergillus niger I-1472. Enzym. Microb. Technol. 2002, 31, 1000-1005. [CrossRef]

23. Ridley, B.L.; O'Neill, M.A.; Mohnen, D. Pectins: Structure, biosynthesis, and oligogalacturonide-related signaling. Phytochemistry. 2001, 57, 929-967. [CrossRef]

24. Castillo-Israel, K.; Baguio, S.; Diasanta, M.; Lizardo, R.; Dizon, E.; Mejico, M. Extraction and characterization of pectin from Saba banana [Musa'saba'(Musa acuminata x Musa balbisiana)] peel wastes: A preliminary study. Int. Food Res. J. $2015,22$.

25. Rosenbohm, C.; Lundt, I.; Christensen, T.I.; Young, N.G. Chemically methylated and reduced pectins: Preparation, characterisation by 1 H NMR spectroscopy, enzymatic degradation, and gelling properties. Carbohydr. Res. 2003, 338, 637-649. [CrossRef]

26. Wandee, Y.; Uttapap, D.; Mischnick, P. Yield and structural composition of pomelo peel pectins extracted under acidic and alkaline conditions. Food Hydrocoll. 2019, 87, 237-244. [CrossRef] 
27. Kulkarni, S.; Vijayanand, P. Effect of extraction conditions on the quality characteristics of pectin from passion fruit peel (Passiflora edulis f. flavicarpa L.). LWT-Food Sci. Technol. 2010, 43, 1026-1031. [CrossRef]

28. Stephen, A.M. Food Polysaccharides and Their Applications; CRC Press: Florida, FL, USA, 1995; Volume 67.

29. Phillips, G.O.; Williams, P.A. Handbook of Hydrocolloids; Elsevier: Amsterdam, The Netherlands, 2009.

30. Garti, N.; Leser, M.E. Emulsification properties of hydrocolloids. Polym. Adv. Technol. 2001, 12, 123-135. [CrossRef]

31. Matia-Merino, L.; Lau, K.; Dickinson, E. Effects of low-methoxyl amidated pectin and ionic calcium on rheology and microstructure of acid-induced sodium caseinate gels. Food Hydrocoll. 2004, 18, 271-281. [CrossRef]

32. Chen, J.; Niu, X.; Dai, T.; Hua, H.; Feng, S.; Liu, C.; McClements, D.J.; Liang, R. Amino acid-amidated pectin: Preparation and characterization. Food Chem. 2020, 309, 125768. [CrossRef]

33. Turakhozhaev, M.; Khodzhaev, M. Plant pectin substances. Methods of isolating pectin substances. Chem. Nat. Compd. 1993, 29, 558-565. [CrossRef]

34. Freitas, C.; Sousa, R.; Dias, M.; Coimbra, J. Extraction of Pectin from Passion Fruit Peel. Food Eng. Rev. 2020, 12, 460-472. [CrossRef]

35. Li, D.-Q.; Jia, X.; Wei, Z.; Liu, Z.-Y. Box-Behnken experimental design for investigation of microwave-assisted extracted sugar beet pulp pectin. Carbohydr. Polym. 2012, 88, 342-346. [CrossRef]

36. Mao, G.; Wu, D.; Wei, C.; Tao, W.; Ye, X.; Linhardt, R.J.; Orfila, C.; Chen, S. Reconsidering conventional and innovative methods for pectin extraction from fruit and vegetable waste: Targeting rhamnogalacturonan I. Trends Food Sci. Technol. 2019, 94, 65-78. [CrossRef]

37. Dranca, F.; Oroian, M. Extraction, purification and characterization of pectin from alternative sources with potential technological applications. Food Res. Int. 2018, 113, 327-350. [CrossRef]

38. Kaya, M.; Sousa, A.G.; Crépeau, M.-J.; Sørensen, S.O.; Ralet, M.-C. Characterization of citrus pectin samples extracted under different conditions: Influence of acid type and pH of extraction. Ann. Bot. 2014, 114, 1319-1326. [CrossRef] [PubMed]

39. Yang, J.-S.; Mu, T.-H.; Ma, M.-M. Extraction, structure, and emulsifying properties of pectin from potato pulp. Food Chem. 2018, 244, 197-205. [CrossRef] [PubMed]

40. Rodsamran, P.; Sothornvit, R. Microwave heating extraction of pectin from lime peel: Characterization and properties compared with the conventional heating method. Food Chem. 2019, 278, 364-372. [CrossRef] [PubMed]

41. Fishman, M.L.; Chau, H.K.; Hoagland, P.D.; Hotchkiss, A.T. Microwave-assisted extraction of lime pectin. Food Hydrocoll. 2006, 20, 1170-1177. [CrossRef]

42. Canteri-Schemin, M.H.; Fertonani, H.C.R.; Waszczynskyj, N.; Wosiacki, G. Extraction of pectin from apple pomace. Braz. Arch Biol. Technol. 2005, 48, 259-266. [CrossRef]

43. Rasheed, A.M. Effect of different acids, heating time and particle size on pectin extraction from watermelon rinds. J. Kerbala Univ. 2008, 6, 234-243.

44. Abidin, S.A.S.Z.; Badarudin, N.S.A.; Ab Mutalib, S.R. Ultrasound-Assisted Extraction Increases Pectin Yield from Watermelon (Citrullus Lanatus) Rind. In Proceedings of the 2020 11th IEEE Control and System Graduate Research Colloquium (ICSGRC), Shah Alam, Malaysia, 8 August 2020; pp. 291-294.

45. Hu, W.; Zhao, Y.; Yang, Y.; Zhang, H.; Ding, C.; Hu, C.; Zhou, L.; Zhang, Z.; Yuan, S.; Chen, Y. Microwave-assisted extraction, physicochemical characterization and bioactivity of polysaccharides from Camptotheca acuminata fruits. Int. J. Biol. Macromol. 2019, 133, 127-136. [CrossRef]

46. Sayah, M.Y.; Chabir, R.; Benyahia, H.; Rodi Kandri, Y.; Ouazzani Chahdi, F.; Touzani, H.; Errachidi, F. Yield, esterification degree and molecular weight evaluation of pectins isolated from orange and grapefruit peels under different conditions. PLoS One 2016, 11, e0161751. [CrossRef]

47. Hamidon, N.H.; Zaidel, D.N.A. Effect of extraction conditions on pectin yield extracted from sweet potato peels residues using hydrochloric acid. Chem. Eng. Trans. 2017, 56, 979-984.

48. Andersen, N.M.; Cognet, T.; Santacoloma, P.; Larsen, J.; Armagan, I.; Larsen, F.; Gernaey, K.; Abildskov, J.; Huusom, J.K. Dynamic modelling of pectin extraction describing yield and functional characteristics. J. Food Eng. 2017, 192, 61-71. [CrossRef]

49. Wang, W.; Ma, X.; Xu, Y.; Cao, Y.; Jiang, Z.; Ding, T.; Ye, X.; Liu, D. Ultrasound-assisted heating extraction of pectin from grapefruit peel: Optimization and comparison with the conventional method. Food Chem. 2015, 178, 106-114. [CrossRef]

50. Mesbahi, G.; Jamalian, J.; Farahnaky, A. A comparative study on functional properties of beet and citrus pectins in food systems. Food Hydrocoll. 2005, 19, 731-738. [CrossRef]

51. Pasandide, B.; Khodaiyan, F.; Mousavi, Z.; Hosseini, S.S. Pectin extraction from citron peel: Optimization by Box-Behnken response surface design. Food Sci. Biotechnol. 2018, 27, 997-1005. [CrossRef]

52. Marenda, F.R.B.; Colodel, C.; Canteri, M.H.G.; de Olivera Müller, C.M.; Amante, E.R.; de Oliveira Petkowicz, C.L.; de Mello Castanho Amboni, R.D. Investigation of cell wall polysaccharides from flour made with waste peel from unripe banana (Musa sapientum) biomass. J. Sci. Food Agric. 2019, 99, 4363-4372. [CrossRef] [PubMed]

53. Kazemi, M.; Khodaiyan, F.; Hosseini, S.S.; Najari, Z. An integrated valorization of industrial waste of eggplant: Simultaneous recovery of pectin, phenolics and sequential production of pullulan. Waste Manag. 2019, 100, 101-111. [CrossRef]

54. Al-Amoudi, R.H.; Taylan, O.; Kutlu, G.; Can, A.M.; Sagdic, O.; Dertli, E.; Yilmaz, M.T. Characterization of chemical, molecular, thermal and rheological properties of medlar pectin extracted at optimum conditions as determined by Box-Behnken and ANFIS models. Food Chem. 2019, 271, 650-662. [CrossRef] 
55. Methacanon, P.; Krongsin, J.; Gamonpilas, C. Pomelo (Citrus maxima) pectin: Effects of extraction parameters and its properties. Food Hydrocoll. 2014, 35, 383-391. [CrossRef]

56. Colodel, C.; de Oliveira Petkowicz, C.L. Acid extraction and physicochemical characterization of pectin from cubiu (Solanum sessiliflorum D.) fruit peel. Food Hydrocoll. 2019, 86, 193-200. [CrossRef]

57. Morales-Martínez, Y.; del Rocío López-Cuellar, M.; Chavarría-Hernández, N.; Rodríguez-Hernández, A.I. Rheological behaviour of acetylated pectins from cactus pear fruits (Opuntia albicarpa and O. matudae). Food Hydrocoll. 2018, 85, 110-119. [CrossRef]

58. Priyangini, F.; Walde, S.G.; Chidambaram, R. Extraction optimization of pectin from cocoa pod husks (Theobroma cacao L.) with ascorbic acid using response surface methodology. Carbohydr. Polym. 2018, 202, 497-503. [CrossRef] [PubMed]

59. Patova, O.; Smirnov, V.; Golovchenko, V.; Vityazev, F.; Shashkov, A.; Popov, S. Structural, rheological and antioxidant properties of pectins from Equisetum arvense L. and Equisetum sylvaticum L. Carbohydr. Polym. 2019, 209, 239-249. [CrossRef] [PubMed]

60. Altaf, U.; Immanuel, G.; Iftikhar, F. Extraction and characterization of pectin derived from papaya (Carica papaya Linn.) peel. Int. J. Sci. Eng. Technol. 2015, 3, 970-974.

61. Jafari, F.; Khodaiyan, F.; Kiani, H.; Hosseini, S.S. Pectin from carrot pomace: Optimization of extraction and physicochemical properties. Carbohydr. Polym. 2017, 157, 1315-1322. [CrossRef]

62. Colodel, C.; Vriesmann, L.C.; de Oliveira Petkowicz, C.L. Rheological characterization of a pectin extracted from ponkan (Citrus reticulata blanco cv. ponkan) peel. Food Hydrocoll. 2019, 94, 326-332. [CrossRef]

63. Pi, F.; Liu, Z.; Guo, X.; Guo, X.; Meng, H. Chicory root pulp pectin as an emulsifier as compared to sugar beet pectin. Part 1: Influence of structure, concentration, counterion concentration. Food Hydrocoll. 2019, 89, 792-801. [CrossRef]

64. Zhang, C.; Zhu, X.; Zhang, F.; Yang, X.; Ni, L.; Zhang, W.; Liu, Z.; Zhang, Y. Improving viscosity and gelling properties of leaf pectin by comparing five pectin extraction methods using green tea leaf as a model material. Food Hydrocoll. 2020, $98,105246$. [CrossRef]

65. Yapo, B.; Besson, V.; Grah, A.; Kouassi, K.; Dago, G. Macromolecular and viscoelastic properties of low methoxy pectin from cashew apple pomace. Univ. J. Food Nutr. Sci 2014, 2, 1-6.

66. Yang, X.; Nisar, T.; Hou, Y.; Gou, X.; Sun, L.; Guo, Y. Pomegranate peel pectin can be used as an effective emulsifier. Food Hydrocoll. 2018, 85, 30-38. [CrossRef]

67. Sato, M.d.F.; Rigoni, D.C.; Canteri, M.H.G.; Petkowicz, C.L.d.O.; Nogueira, A.; Wosiacki, G. Chemical and instrumental characterization of pectin from dried pomace of eleven apple cultivars. Acta Scientiarum. Agron. 2011, 33, $383-389$.

68. Wang, W.; Ma, X.; Jiang, P.; Hu, L.; Zhi, Z.; Chen, J.; Ding, T.; Ye, X.; Liu, D. Characterization of pectin from grapefruit peel: A comparison of ultrasound-assisted and conventional heating extractions. Food Hydrocoll. 2016, 61, 730-739. [CrossRef]

69. Koh, P.; Leong, C.; Noranizan, M. Microwave-assisted extraction of pectin from jackfruit rinds using different power levels. Int. Food Res. J. 2014, 21, 2091.

70. Jiang, L.N.; Shang, J.J.; He, L.B.; Dan, J.M. Comparisons of microwave-assisted and conventional heating extraction of pectin from seed watermelon peel. Adv. Mater. Res. 2012, 550-553, 1801-1806. [CrossRef]

71. Yang, Y.; Wang, Z.; Hu, D.; Xiao, K.; Wu, J.-Y. Efficient extraction of pectin from sisal waste by combined enzymatic and ultrasonic process. Food Hydrocoll. 2018, 79, 189-196. [CrossRef]

72. Adetunji, L.R.; Adekunle, A.; Orsat, V.; Raghavan, V. Advances in the pectin production process using novel extraction techniques: A review. Food Hydrocoll. 2017, 62, 239-250. [CrossRef]

73. Routray, W.; Orsat, V. Microwave-assisted extraction of flavonoids: A review. Food Bioprocess Technol. 2012, 5, 409-424. [CrossRef]

74. Fishman, M.L.; Chau, H.K.; Hoagland, P.; Ayyad, K. Characterization of pectin, flash-extracted from orange albedo by microwave heating, under pressure. Carbohydr. Res. 1999, 323, 126-138. [CrossRef]

75. Bagherian, H.; Ashtiani, F.Z.; Fouladitajar, A.; Mohtashamy, M. Comparisons between conventional, microwave-and ultrasoundassisted methods for extraction of pectin from grapefruit. Chem. Eng. Process. Process. Intensif. 2011, 50, 1237-1243. [CrossRef]

76. Maran, J.P.; Sivakumar, V.; Thirugnanasambandham, K.; Sridhar, R. Microwave assisted extraction of pectin from waste Citrullus lanatus fruit rinds. Carbohydr. Polym. 2014, 101, 786-791. [CrossRef]

77. Hua, X.; Wang, K.; Yang, R.; Kang, J.; Zhang, J. Rheological properties of natural low-methoxyl pectin extracted from sunflower head. Food Hydrocoll. 2015, 44, 122-128. [CrossRef]

78. Poojary, M.M.; Orlien, V.; Passamonti, P.; Olsen, K. Enzyme-assisted extraction enhancing the umami taste amino acids recovery from several cultivated mushrooms. Food Chem. 2017, 234, 236-244. [CrossRef] [PubMed]

79. Munarin, F.; Tanzi, M.C.; Petrini, P. Advances in biomedical applications of pectin gels. Int. J. Biol. Macromol. 2012, 51, 681-689. [CrossRef] [PubMed]

80. Guo, X.; Ye, X.; Sun, Y.; Wu, D.; Wu, N.; Hu, Y.; Chen, S. Ultrasound effects on the degradation kinetics, structure, and antioxidant activity of sea cucumber fucoidan. J. Agric. Food Chem. 2014, 62, 1088-1095. [CrossRef] [PubMed]

81. Rutkowska, M.; Namieśnik, J.; Konieczka, P. Ultrasound-Assisted Extraction. In The Application of Green Solvents in Separation Processes; Pena-Pereira, F., Tobiszewski, M., Eds.; Elsevier: Amsterdam, The Netherlands, 2017; pp. 301-324.

82. Li, L.; Fang, Y.; Vreeker, R.; Appelqvist, I.; Mendes, E. Reexamining the egg-box model in calcium- alginate gels with X-ray diffraction. Biomacromolecules 2007, 8, 464-468. [CrossRef]

83. Azmir, J.; Zaidul, I.S.M.; Rahman, M.; Sharif, K.; Mohamed, A.; Sahena, F.; Jahurul, M.; Ghafoor, K.; Norulaini, N.; Omar, A. Techniques for extraction of bioactive compounds from plant materials: A review. J. Food Eng. 2013, 117, 426-436. [CrossRef] 
84. Cravotto, G.; Cintas, P. Power ultrasound in organic synthesis: Moving cavitational chemistry from academia to innovative and large-scale applications. Chem. Soc. Rev. 2006, 35, 180-196. [CrossRef] [PubMed]

85. Ilghami, A.; Ghanbarzadeh, S.; Hamishehkar, H. Optimization of the ultrasonic-assisted extraction of phenolic compounds, ferric reducing activity and antioxidant activity of the beta vulgaris using response surface methodology. Pharm. Sci. 2015, 21, 46-50. [CrossRef]

86. Llano, K.R.A.; Marsellés-Fontanet, A.R.; Martín-Belloso, O.; Soliva-Fortuny, R. Impact of pulsed light treatments on antioxidant characteristics and quality attributes of fresh-cut apples. Innov. Food Sci. Emerg. Technol. 2016, 33, 206-215. [CrossRef]

87. Gharibzahedi, S.M.T.; Smith, B.; Guo, Y. Pectin extraction from common fig skin by different methods: The physicochemical, rheological, functional, and structural evaluations. Int. J. Biol. Macromol. 2019, 136, 275-283. [CrossRef] [PubMed]

88. Misra, N.; Tiwari, B.; Raghavarao, K.; Cullen, P. Nonthermal plasma inactivation of food-borne pathogens. Food Eng. Rev. 2011, 3, 159-170. [CrossRef]

89. Misra, N.; Martynenko, A.; Chemat, F.; Paniwnyk, L.; Barba, F.J.; Jambrak, A.R. Thermodynamics, transport phenomena, and electrochemistry of external field-assisted nonthermal food technologies. Crit. Rev. Food Sci. Nutr. 2018, 58, 1832-1863. [CrossRef] [PubMed]

90. Pacheco, M.T.; Villamiel, M.; Moreno, R.; Moreno, F.J. Structural and rheological properties of pectins extracted from industrial sugar beet by-products. Molecules 2019, 24, 392. [CrossRef]

91. Campbel, M. Watermelond rind pectin extraction. Submitted to the Faculty of the Graduate College of the Oklahoma State University, 2006.

92. Hadkar, U.; Dhruv, N.; Malode, Y.; Chavan, B. Microwave assisted extraction of phytoconstituents. Asian J. Phytomedicine Clin. Res. 2013, 2, 73-86.

93. Korish, M. Potential utilization of Citrullus lanatus var. Colocynthoides waste as a novel source of pectin. J. Food Sci. Technol. 2015, 52, 2401-2407. [CrossRef]

94. Dominiak, M.; Søndergaard, K.M.; Wichmann, J.; Vidal-Melgosa, S.; Willats, W.G.; Meyer, A.S.; Mikkelsen, J.D. Application of enzymes for efficient extraction, modification, and development of functional properties of lime pectin. Food Hydrocoll. 2014, 40, 273-282. [CrossRef]

95. Fissore, E.N.; Rojas, A.M.; Gerschenson, L.N.; Williams, P.A. Butternut and beetroot pectins: Characterization and functional properties. Food Hydrocoll. 2013, 31, 172-182. [CrossRef]

96. Bayar, N.; Bouallegue, T.; Achour, M.; Kriaa, M.; Bougatef, A.; Kammoun, R. Ultrasonic extraction of pectin from Opuntia ficus indica cladodes after mucilage removal: Optimization of experimental conditions and evaluation of chemical and functional properties. Food Chem. 2017, 235, 275-282. [CrossRef]

97. Mzoughi, Z.; Abdelhamid, A.; Rihouey, C.; Le Cerf, D.; Bouraoui, A.; Majdoub, H. Optimized extraction of pectin-like polysaccharide from Suaeda fruticosa leaves: Characterization, antioxidant, anti-inflammatory and analgesic activities. Carbohydr. Polym. 2018, 185, 127-137. [CrossRef]

98. Talekar, S.; Patti, A.F.; Vijayraghavan, R.; Arora, A. Complete utilization of waste pomegranate peels to produce a hydrocolloid, punicalagin rich phenolics, and a hard carbon electrode. ACS Sustain. Chem. Eng. 2018, 6, 16363-16374. [CrossRef]

99. Maran, J.P.; Priya, B.; Al-Dhabi, N.A.; Ponmurugan, K.; Moorthy, I.G.; Sivarajasekar, N. Ultrasound assisted citric acid mediated pectin extraction from industrial waste of Musa balbisiana. Ultrason. Sonochemistry 2017, 35, 204-209. [CrossRef] [PubMed]

100. Kazemi, M.; Khodaiyan, F.; Hosseini, S.S. Eggplant peel as a high potential source of high methylated pectin: Ultrasonic extraction optimization and characterization. LWT 2019, 105, 182-189. [CrossRef]

101. de Oliveira, C.F.; Giordani, D.; Lutckemier, R.; Gurak, P.D.; Cladera-Olivera, F.; Marczak, L.D.F. Extraction of pectin from passion fruit peel assisted by ultrasound. LWT-Food Sci. Technol. 2016, 71, 110-115. [CrossRef]

102. Li, X.-S.; Liu, Z.-Y.; Lu, B.-S. Ultrasonic-assisted extraction of pectin from chaenomeles. J. South Univ. 2014, 21, 4115-4120. [CrossRef]

103. Shivamathi, C.; Moorthy, I.G.; Kumar, R.V.; Soosai, M.R.; Maran, J.P.; Kumar, R.S.; Varalakshmi, P. Optimization of ultrasound assisted extraction of pectin from custard apple peel: Potential and new source. Carbohydr. Polym. 2019, 225, 115240. [CrossRef]

104. Wang, S.; Chen, F.; Wu, J.; Wang, Z.; Liao, X.; Hu, X. Optimization of pectin extraction assisted by microwave from apple pomace using response surface methodology. J. Food Eng. 2007, 78, 693-700. [CrossRef]

105. Dao, T.A.T.; Webb, H.K.; Malherbe, F. Optimization of pectin extraction from fruit peels by response surface method: Conventional versus microwave-assisted heating. Food Hydrocoll. 2021, 113, 106475.

106. Rahmani, Z.; Khodaiyan, F.; Kazemi, M.; Sharifan, A. Optimization of microwave-assisted extraction and structural characterization of pectin from sweet lemon peel. Int. J. Biol. Macromol. 2020, 147, 1107-1115. [CrossRef]

107. Yoo, S.H.; Lee, B.H.; Lee, H.; Lee, S.; Bae, I.Y.; Lee, H.G.; Fishman, M.L.; Chau, H.K.; Savary, B.J.; Hotchkiss, A.T., Jr. Structural characteristics of pumpkin pectin extracted by microwave heating. J. Food Sci. 2012, 77, C1169-C1173. [CrossRef]

108. Hartati, I.; Riwayati, I.; Subekti, E. Microwave Assisted Extraction of Watermelon Rind Pectin with Different Kind of Acid Solution. ICETIA2014 2014, 27-30.

109. Swamy, G.J.; Muthukumarappan, K. Optimization of continuous and intermittent microwave extraction of pectin from banana peels. Food Chem. 2017, 220, 108-114. [CrossRef] [PubMed]

110. Hosseini, S.S.; Khodaiyan, F.; Yarmand, M.S. Optimization of microwave assisted extraction of pectin from sour orange peel and its physicochemical properties. Carbohydr. Polym. 2016, 140, 59-65. [CrossRef] [PubMed] 
111. Kazemi, M.; Khodaiyan, F.; Labbafi, M.; Hosseini, S.S.; Hojjati, M. Pistachio green hull pectin: Optimization of microwave-assisted extraction and evaluation of its physicochemical, structural and functional properties. Food Chem. 2019, 271, 663-672. [CrossRef] [PubMed]

112. Schols, H.A.; Bakx, E.J.; Schipper, D.; Voragen, A.G. A xylogalacturonan subunit present in the modified hairy regions of apple pectin. Carbohydr. Res. 1995, 279, 265-279. [CrossRef]

113. Ross-Murphy, S.B. Rheological characterisation of gels 1. J. Texture Stud. 1995, 26, 391-400. [CrossRef]

114. Sato, Y.; Miyawaki, O. Analysis of intermolecular interaction among pectin molecules in aqueous sugar solutions. Food Sci. Technol. Res. 2008, 14, 232-238. [CrossRef]

115. Oakenfull, D.; Scott, A. Hydrophobic interaction in the gelation of high methoxyl pectins. J. Food Sci. 1984, 49, 1093-1098. [CrossRef]

116. Williams, P.A.; Phillips, G.O. Introduction to Food Hydrocolloids. In Handbook of Hydrocolloids, 3rd ed.; Williams, P.A., Phillips, G.O., Eds.; Elsevier: Amsterdam, The Netherlands, 2021; pp. 3-26.

117. Thakur, B.R.; Singh, R.K.; Handa, A.K.; Rao, M. Chemistry and uses of pectin-A review. Crit. Rev. Food Sci. Nutr. 1997, 37, 47-73. [CrossRef]

118. Morris, G.; Foster, T.; Harding, S. The effect of the degree of esterification on the hydrodynamic properties of citrus pectin. Food Hydrocoll. 2000, 14, 227-235. [CrossRef]

119. Rouse, A.; Atkins, C.; Moore, E. The occurrence and evaluation of pectin in component parts of Valencia oranges during maturation. Proc. Fla. State Hortic. Soc. 1962, 75, 307-311.

120. Günter, E.A.; Popeyko, O.V.; Markov, P.A.; Martinson, E.A.; Litvinets, S.G.; Durnev, E.A.; Popov, S.V.; Ovodov, Y.S. Swelling and morphology of calcium pectinate gel beads obtained from Silene vulgaris callus modified pectins. Carbohydr. Polym. 2014, 103, 550-557. [CrossRef]

121. Chan, S.Y.; Choo, W.S.; Young, D.J.; Loh, X.J. Pectin as a rheology modifier: Origin, structure, commercial production and rheology. Carbohydr. Polym. 2017, 161, 118-139. [CrossRef] [PubMed]

122. Brax, M.; Schaumann, G.E.; Diehl, D. Gel formation mechanism and gel properties controlled by $\mathrm{Ca}^{2+}$ in chia seed mucilage and model substances. J. Plant Nutr. Soil Sci. 2019, 182, 92-103. [CrossRef]

123. Cao, L.; Lu, W.; Mata, A.; Nishinari, K.; Fang, Y. Egg-box model-based gelation of alginate and pectin: A review. Carbohydr. Polym. 2020, 242, 116389. [CrossRef]

124. Celus, M.; Kyomugasho, C.; Salvia-Trujillo, L.; Van Audenhove, J.; Van Loey, A.M.; Grauwet, T.; Hendrickx, M.E. Interactions between citrus pectin and $\mathrm{Zn}^{2+}$ or $\mathrm{Ca}^{2+}$ and associated in vitro $\mathrm{Zn}^{2+}$ bioaccessibility as affected by degree of methylesterification and blockiness. Food Hydrocoll. 2018, 79, 319-330. [CrossRef]

125. Ngouémazong, D.E.; Jolie, R.P.; Cardinaels, R.; Fraeye, I.; Van Loey, A.; Moldenaers, P.; Hendrickx, M. Stiffness of Ca ${ }^{2+}$-pectin gels: Combined effects of degree and pattern of methylesterification for various $\mathrm{Ca}^{2+}$ concentrations. Carbohydr. Res. 2012, 348, 69-76. [CrossRef]

126. Ralet, M.-C.; Crépeau, M.-J.; Buchholt, H.-C.; Thibault, J.-F. Polyelectrolyte behaviour and calcium binding properties of sugar beet pectins differing in their degrees of methylation and acetylation. Biochem. Eng. J. 2003, 16, 191-201. [CrossRef]

127. Han, W.; Meng, Y.; Hu, C.; Dong, G.; Qu, Y.; Deng, H.; Guo, Y. Mathematical model of $\mathrm{Ca}^{2+}$ concentration, $\mathrm{pH}$, pectin concentration and soluble solids (sucrose) on the gelation of low methoxyl pectin. Food Hydrocoll. 2017, 66, 37-48. [CrossRef]

128. Elleuch, M.; Bedigian, D.; Roiseux, O.; Besbes, S.; Blecker, C.; Attia, H. Dietary fibre and fibre-rich by-products of food processing: Characterisation, technological functionality and commercial applications: A review. Food Chem. 2011, 124, 411-421. [CrossRef]

129. Romdhane, M.B.; Haddar, A.; Ghazala, I.; Jeddou, K.B.; Helbert, C.B.; Ellouz-Chaabouni, S. Optimization of polysaccharides extraction from watermelon rinds: Structure, functional and biological activities. Food Chem. 2017, 216, 355-364. [CrossRef]

130. Xu, M. Polysaccharides from Sunflower Stalk Pith: Chemical, Structural, and Partial Physicochemical Characterization. Food Hydrocoll. 2020, 100, 105082. [CrossRef]

131. Namir, M.; Siliha, H.; Ramadan, M.F. Fiber pectin from tomato pomace: Characteristics, functional properties and application in low-fat beef burger. J. Food Meas. Charact. 2015, 9, 305-312. [CrossRef]

132. Asgari, K.; Labbafi, M.; Khodaiyan, F.; Kazemi, M.; Hosseini, S.S. High-methylated pectin from walnut processing wastes as a potential resource: Ultrasound assisted extraction and physicochemical, structural and functional analysis. Int. J. Biol. Macromol. 2020, 152, 1274-1282. [CrossRef] [PubMed]

133. Rubio-Senent, F.; Rodríguez-Gutiérrez, G.; Lama-Muñoz, A.; Fernández-Bolaños, J. Pectin extracted from thermally treated olive oil by-products: Characterization, physico-chemical properties, in vitro bile acid and glucose binding. Food Hydrocoll. 2015, 43, 311-321. [CrossRef]

134. McClements, D.J. Emulsion design to improve the delivery of functional lipophilic components. Annu. Rev. Food Sci. Technol. 2010, 1, 241-269. [CrossRef]

135. Verkempinck, S.; Kyomugasho, C.; Salvia-Trujillo, L.; Denis, S.; Bourgeois, M.; Van Loey, A.; Hendrickx, M.; Grauwet, T. Emulsion stabilizing properties of citrus pectin and its interactions with conventional emulsifiers in oil-in-water emulsions. Food Hydrocoll. 2018, 85, 144-157. [CrossRef]

136. Gunasekaran, S.; Ak, M.M. Dynamic oscillatory shear testing of foods—selected applications. Trends Food Sci.Technol. 2000, 11, 115-127. [CrossRef] 
137. Dickinson, E. Hydrocolloids at interfaces and the influence on the properties of dispersed systems. Food Hydrocoll. 2003, 17, 25-39. [CrossRef]

138. Ngouémazong, E.D.; Christiaens, S.; Shpigelman, A.; Van Loey, A.; Hendrickx, M. The emulsifying and emulsion-stabilizing properties of pectin: A review. Compr. Rev. Food Sci. Food Saf. 2015, 14, 705-718. [CrossRef]

139. Chanamai, R.; McClements, D. Depletion flocculation of beverage emulsions by gum arabic and modified starch. J. Food Sci. 2001, 66, 457-463. [CrossRef]

140. Alba, K.; Kontogiorgos, V. Pectin at the oil-water interface: Relationship of molecular composition and structure to functionality. Food Hydrocoll. 2017, 68, 211-218. [CrossRef]

141. Liu, Z.; Pi, F.; Guo, X.; Guo, X.; Yu, S. Characterization of the structural and emulsifying properties of sugar beet pectins obtained by sequential extraction. Food Hydrocoll. 2019, 88, 31-42. [CrossRef]

142. Siew, C.K.; Williams, P.A. Role of protein and ferulic acid in the emulsification properties of sugar beet pectin. J. Agric. Food Chem. 2008, 56, 4164-4171. [CrossRef] [PubMed]

143. Bai, L.; Huan, S.; Li, Z.; McClements, D.J. Comparison of emulsifying properties of food-grade polysaccharides in oil-in-water emulsions: Gum arabic, beet pectin, and corn fiber gum. Food Hydrocoll. 2017, 66, 144-153. [CrossRef]

144. Zykwinska, A.; Gaillard, C.; Boiffard, M.-H.; Thibault, J.-F.; Bonnin, E. “Green labelled" pectins with gelling and emulsifying properties can be extracted by enzymatic way from unexploited sources. Food Hydrocoll. 2009, 23, 2468-2477. [CrossRef]

145. Fissore, E.N.; Rojas, A.M.; Gerschenson, L.N. Rheological performance of pectin-enriched products isolated from red beet (Beta vulgaris L. var. conditiva) through alkaline and enzymatic treatments. Food Hydrocoll. 2012, 26, 249-260. [CrossRef]

146. Sriamornsak, P. Chemistry of pectin and its pharmaceutical uses: A review. Silpakorn Univ. Int. J. 2003, 3, $206-228$.

147. Linden, G.; Lorient, D. Biochimie Agro-lndustrielle: Valorisation alimentaire de la production agricole. Edition Masson, Paris. J. Biol. Chem. 1994, 193, 265-275.

148. Ptichkina, N.; Markina, O.; Rumyantseva, G. Pectin extraction from pumpkin with the aid of microbial enzymes. Food Hydrocoll. 2008, 22, 192-195. [CrossRef]

149. Min, B.; Lim, J.; Ko, S.; Lee, K.-G.; Lee, S.H.; Lee, S. Environmentally friendly preparation of pectins from agricultural byproducts and their structural/rheological characterization. Bioresour. Technol. 2011, 102, 3855-3860. [CrossRef]

150. Kontogiorgos, V.; Margelou, I.; Georgiadis, N.; Ritzoulis, C. Rheological characterization of okra pectins. Food Hydrocoll. 2012, 29, 356-362. [CrossRef]

151. Zhang, L.; Ye, X.; Ding, T.; Sun, X.; Xu, Y.; Liu, D. Ultrasound effects on the degradation kinetics, structure and rheological properties of apple pectin. Ultrason. Sonochemistry 2013, 20, 222-231. [CrossRef]

152. Akhtar, M.; Dickinson, E.; Mazoyer, J.; Langendorff, V. Emulsion stabilizing properties of depolymerized pectin. Food Hydrocoll. 2002, 16, 249-256. [CrossRef]

153. Cameron, R.G.; Savary, B.J.; Hotchkiss, A.T.; Fishman, M.L. Isolation, characterization, and pectin-modifying properties of a thermally tolerant pectin methylesterase from Citrus sinensis var. Valencia. J. Agric. Food Chem. 2005, 53, 2255-2260. [CrossRef] [PubMed] 